University of Rhode Island

DigitalCommons@URI

Open Access Dissertations

1982

\title{
Androgen Biosynthesis in the Testis
}

Mary A. Acciardi

University of Rhode Island

Follow this and additional works at: https://digitalcommons.uri.edu/oa_diss

\section{Recommended Citation}

Acciardi, Mary A., "Androgen Biosynthesis in the Testis" (1982). Open Access Dissertations. Paper 411. https://digitalcommons.uri.edu/oa_diss/411

This Dissertation is brought to you for free and open access by DigitalCommons@URI. It has been accepted for inclusion in Open Access Dissertations by an authorized administrator of DigitalCommons@URI. For more information, please contact digitalcommons-group@uri.edu. 
ANDROGEN BIOSYNTHESIS IN THE TESTIS:

I. KINETIC CHARACTERIZATION OF THE STEROIDOGENIC PATHWAYS IN GUINEA PIG, RABBIT, DOG AND RAT TESTIS MICROSOMES,

II. THE EFFECT OF ASCORBIC ACID ON 3-B HYDROXYSTEROID:NADOXIDOREDUCTASE ACTIVITY IN THE TESTIS

BY

MARY A. ACCIARDI

A DISSERTATION SUBMITTED IN PARTIAL FULFILLMENT OF THE REQUIREMENTS FOR

THE DEGREE OF

DOCTOR OF PHILOSOPHY

IN

BIOLOGICAL SCIENCES

(FOOD SCIENCE \& NUTRITION)

UNIVERSITY OF RHODE ISLAND

1982 
DOCTOR OF PHILOSOPHY DISSERTATION

OF

MARY A. ACCIARDI

\section{Approved :}

Dissertation Committee

Major Professor
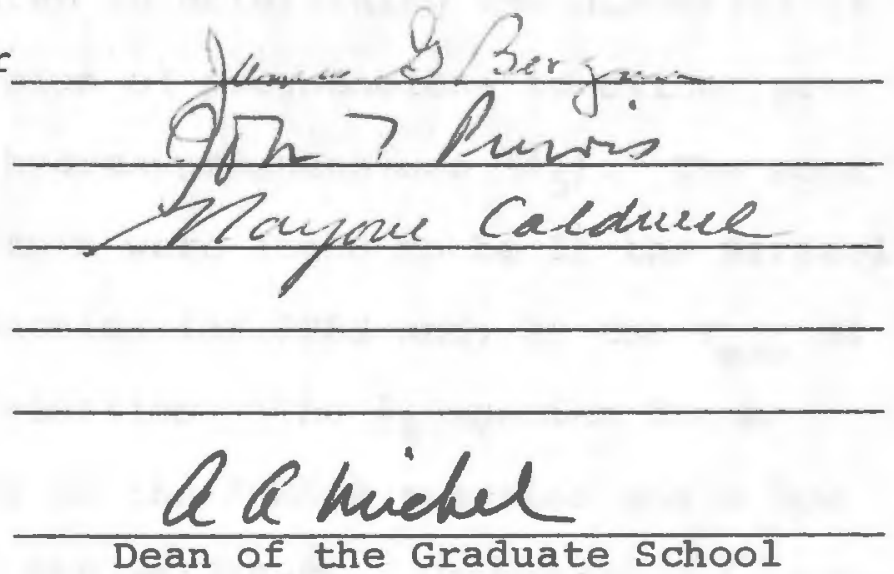


\section{THESIS ABSTRACT}

The kinetic parameters of testicular steroid synthesizing enzymes involved in the $\Delta_{4}$ and $\Delta_{5}$ pathways for testosterone production were examined in four species. Testis microsomes were prepared as a source of steroidogenic enzymes. Radiolabeled steroid-intermediates were used as substrates and products were separated by thin layer chromatography. Michaelis constants, $\left(\mathrm{k}_{0.5}\right)$, and $\mathrm{v}_{\max }$ values were determined for $3 \mathrm{~B}-$ Hydroxysteroid oxidoreductase (EC 1.1.1.145), 17 -Hydroxylase (EC 1.14.99.9) and $C_{17}-C_{20}$ Lyase reactions using $\Delta_{4}$ and $\Delta_{5}$ substrates.

The purpose of the study was to develop a kinetic model for predicting the predominant steroidogenic pathway in mammalian testes. The key step in determining the direction of the pathway is the conversion of pregnenolone to either progesterone $\left(\Delta_{4}\right)$ or to $17 \alpha$-hydroxypregnenolone $\left(\Delta_{5}\right)$. The most definitive kinetic predictors were found to be 1) the Michaelis constant of the 3BHSOR reaction for PREG and, 2) the $V_{\max }$ of the PREG 17a-Hydroxylase reaction. The $\Delta_{4}$ species demonstrate a low $k_{0.5}$ for $P R E G$ in the $3 B H S O R$ reaction and a low $V_{\max }$ for the conversion of PREG $\rightarrow 17$ aPREG. Conversely, $\Delta_{5}$ species demonstrate a high $\mathrm{k}_{0.5}$ for $\mathrm{PREG}$ in the $3 \mathrm{BHSOR}$ reaction and a high $\mathrm{V}_{\max }$ for the hydroxylation. The relative affinity of 3BHSOR and 17a-Hydroxylase for PREG was found to be a useful predictor of the predominant pathway. A high ratio, indicating greater affinity of the hydroxylase for PREG, favors 
conversion to $\Delta_{5}$ steroids and a low ratio is indicative of the $\Delta_{4}$ pathway. Several species were shown to employ mixed $\Delta_{4}$ and $\Delta_{5}$ pathways in the production of testosterone.

Differing kinetic parameters and the absence of lyase activity in the opposite,(nonfavored), pathway in the dog, rabbit and guinea pig are evaluated as evidence for the existence of hydroxylase and lyaseactivities as four distinct proteins. Additionally, a soluble $\mathrm{C}_{17}-\mathrm{C}_{20}$ lyase, with dual nucleotide specificity, was identified in the dog. Regulation of testosterone biosynthesis is discussed in relation to hydroxylase and lyase activity in the four species.

Similar procedures were employed to evaluate the role of ascorbic acid in steroid synthesis. Guinea pigs with latent hypovitaminosis $\mathrm{C}$ were used as a model for evaluation of the effect of ascorbic acid on 3 BHSOR activity. The enzyme was inhibited 37-76\% for the variaus $\Delta_{5}$ substrates by the hypovitaminosis C pretreatment. Partial reversal of inhibition could be obtained by adding ascorbate or dehydroascorbate to in vitro incubations. 
TABLE OF CONIENIS

PAGE

LIST OF FIGURES ............. . . . v LIST OF TABLES ................. vii

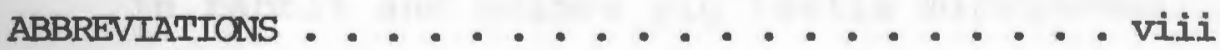
PREFACE .................. $\mathrm{x}$ SECTION ONE

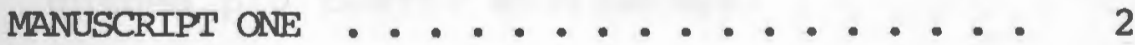

MANUSCRIPT TWO ................. 58

SECTION TWO

HISTORICAL . . . . . . . . 89

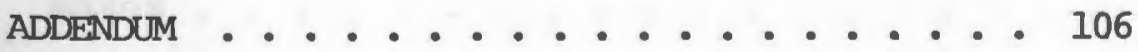

BIBLIOGRAPHY ............. 111 


\section{IIST OF FIGURES}

SECTION ONE

MANUSCRIPT I.

1. Steroidogenic pathways in mammalian testis microsomes.... . . . . . . . . . . . . .

2. Lineweaver-Burk replots of PREG:3BHSOR reactions in rabbit and guinea pig testis microsomes. . .

3. Lineweaver-Burk replots of 17PREG:3BHSOR reactions in rabbit and guinea pig testis microsomes... .

4. Lineweaver-Burk replots of $\mathrm{DHEA}: 3 \mathrm{BHSO}$ reactions in rabbit and guinea pig testis microsomes. . .

5. Lineweaver-Burk replots of ADIOL:3BHSOR reactions in rabbit and guinea pig testes microsomes. . . .

6. Michaelis-Menton plot of $A D I O L \rightarrow T$ reaction in guinea pig testis microsomes. . . . . . . . . .

7. Lineweaver-Burk replots of PREG:17aHydroxylase reactions in rabbit and guinea pig testis microsomes . . . . . . . . . . . . . . . . .

8. Lineweaver-Burk replots of PROG:17atiydroxylase reactions in rabbit and guinea pig testis microsomes . . . . . . . . . . . . . . . . . . .

9. Lineweaver-Burk replots of $\mathrm{C}_{17}-\mathrm{C}_{20}$ Lyase:

(17ahydroxypregnenolone dehyaroeplandrosterone) in rabbit testis microsomes . . . . . . . . . .

10. Lineweaver-Burk replot of $\mathrm{C}_{17}-\mathrm{C}_{20}$ Lyase:

(17ahydroxyprogesterone $\rightarrow$ andrestendione) in guinea pig testis microsomes. . . . . . . . . .

11. Comparison of steroidogenic pathways for testosterone biosynthesis in rabbit, guinea pig, dog and rat testis microsomes. . . . . . . .

MANUSCRIPT II:

1. Michaelis-Menton plot of $3 B H S O R$ reaction in guinea pig testis microsomes with varying NAD . . 
2. Lineweaver-Burk replot of 3BHSOR with PREG as substrate in control and deficient guinea pig testis microsomes.

3. Lineweaver-Burk replot of 3BHSOR with 17 «PREG as substrate in control and deficient guinea pig testis microsomes. . . . . . . . . . . .

4. Lineweaver-Burk replot of 3BHSOR with DHEA as substrate in control and deficient guinea pig testis microsomes. . . . . . . . . . . .

5. Lineweaver-Burk replot of 3BHSOR with DHEA as substrate in control and deficient guinea pig testis microsomes. . . . . . . . . . . .

6. Inhibition of 3BHSOR by PROG. Replot of 82 Lineweaver-Burk (I vs. Slope). . . . . . . .

SECTION TWO

APPENDIX

1. Linearity of 3 BHSOR activity with varying protein concentrations in guinea pig testis microsomes . . 108

2. Linearity of $3 B H S O R$ activity with time in guinea pig testis microsomes. 
SECTION ONE

MANUSCRIPT I

I. Comparison of Kinetic Data in Rabbit and Guinea Pig Testis Microsomes. . . . . . . . . . .

II. Cytochrome P-450 Levels of Testis Microsomes in Four Species . . . . . . . . . . . . .

III. Testis Microsomal 3B-Hydroxysteroid Oxidoreductase Activity in Four Species: $k_{0.5}$ and $v_{\max } \cdot$.

IV. Testis Microsomal 17a-Hydroxylase and Lyase Activity in Four Species: $k_{0.5}$ and $v_{\max }$. . . 54

v. Michaelis Constants $\left(k_{0,5}\right)$ for Pregnenolone in 3BHSOR and Hydroxylase Reactions ....... 55

VI. Relationship of 17a-Hydroxylase Activities in Four Species .................

VII. Ratio of Lyase/Hydroxylase Activity for Pregnenolone and Progesterone in Four Species. . .

MANUSCRIPT II

I. Plasma and Testis Microsomal Ascorbic Acid Levels in Control and Hypovitaminosis C Guinea Pig. . . . . . . . . .........

II. Mean Body Weight, Testes Weight and Microsomal Protein in Control and Hypovitaminosis C Guinea Pig.. . . . . . . . . . . .

III. Activity of $3 B H S O R$ in Control and Hypovitaminosis C Guinea Pig Testis Microsomes . . . . .

IV. The Effect of In Vitro Addition of Ascorbic Acid and Dehydroascorb $\overline{i c} \overline{A c} i d$ on 3BHSOR Activity in Testis Microsomes of Guinea Pigs with Hypovitaminosis C 


\section{ABBREVIATIONS}

Lyase $-\mathrm{C}_{17}-\mathrm{C}_{20}$ Lyase

3BHSOR - 3B-Hydroxysteroid:NAD Oxidoreductase (EC 1.1.1.145)

$17 \alpha-H y d r o x y l a s e-17 \alpha-S t e r o i d$ Hydroxylase:NADPH-oxygenoxidoreductase (EC 1.14.99.9)

17BHSOR - 17B-Hydroxysteroid NADH-Oxidoreductase (EC 1.1.1.64)

PROG - Progesterone; Pregn-4-ene-3,20-dione

PREG - Pregnenolone; 3B-Hydroxy pregn-5-ene-20-one

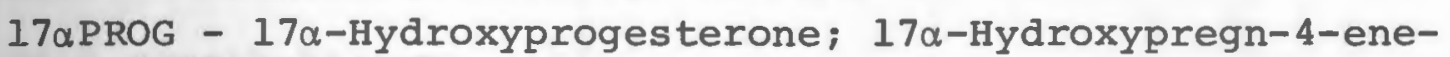
3,20-dione

17aPREG - 17a-Hydroxypregnenolone; 3B, 17aDihydroxypregn-5-ene20-one

DHEA - Dehydroepiandrosterone; 3B-Hydroxyandrost-5-ene-17-one A - Androstenedione; Androst-4-ene-3,17-dione

ADIOL - Androstenediol; Androst-5-ene-3,17-diol

T-Testosterone; $17 \alpha-$ Hydroxyandrost-4-ene-3-one


3-one

$\alpha-$ alpha

$\beta$ - beta

$\Delta$ - delta (indicates unsaturation)

mg - milligram

$\mu g$ - microgram

mm - millimeter

mM - millimolar

$\mathrm{nm}$ - nanomole or nanometer

nM - nanomolar 


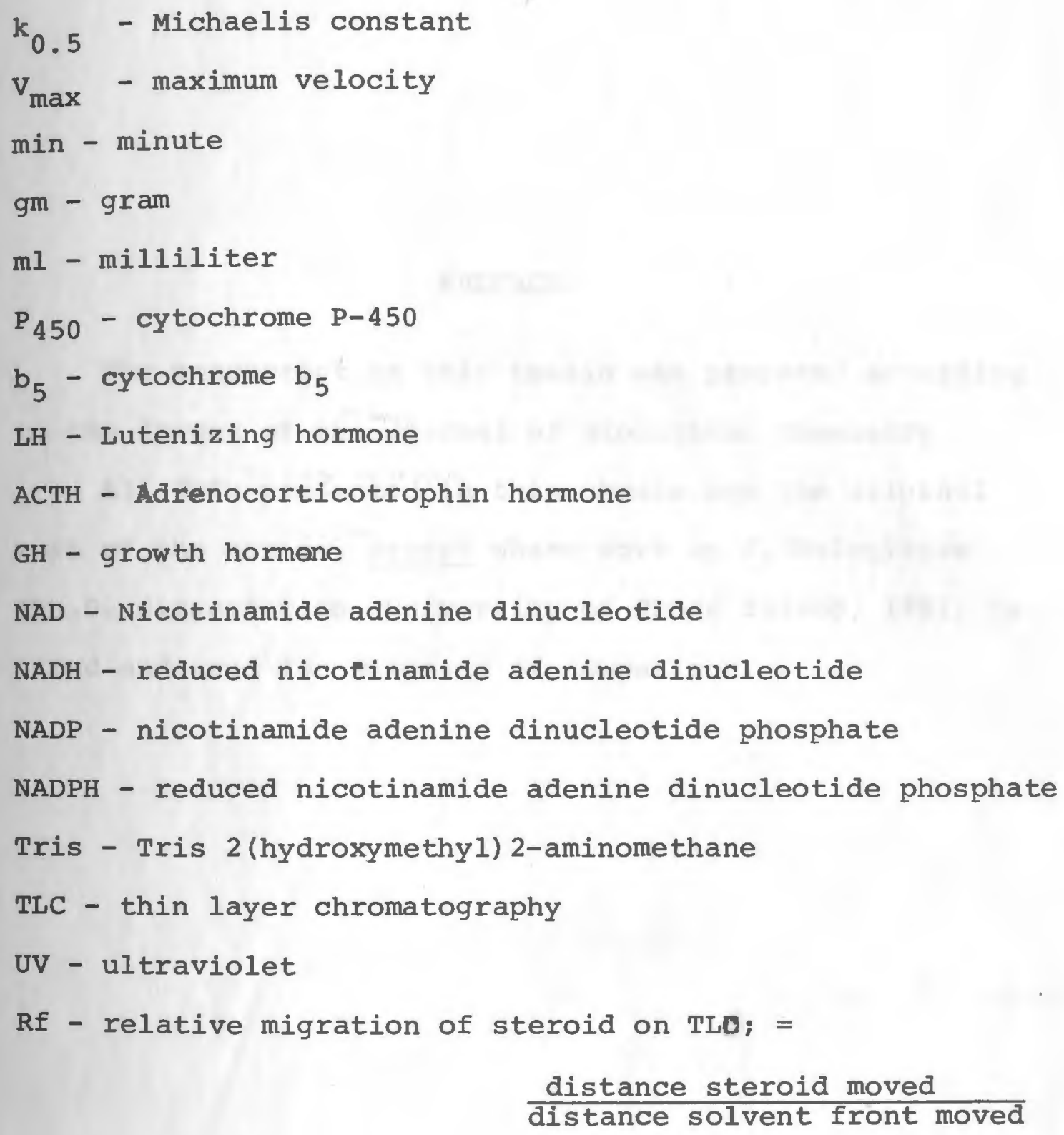




\section{PREFACE}

The manuscript in this thesis was prepared according to the format of the Journal of Biological Chemistry.

All data presented in this thesis are the original work of the author, except where work by J. Hologittas (Ph.D. dissertation, University of Rhode Island, 1981) is cited and used for purposes of comparison. 
I. KINETIC CHARACTERIZATION OF THE STEROIDOGENIC PATHWAYS IN GUINEA PIG, RABBIT, DOG AND RAT TESTIS MICROSOMES 


\section{INTRODUCTION}

The leydig cell of the testis is the principal site of androgen biosynthesis in the male of dimorphic species. The major androgens produced by the testes, androstendione, dehydroepiandrosterone, testosterone and dihydrotestosterone are synthesized from cholesterol $(1,2)$. In all steroidogenic tissues, the initial step is the sidechain cleavage of cholesterol to form pregnenolone (3-6). This step is considered to be rate limiting in androgen biosynthesis and is modulated by the pituitary gonadotrophin, LH. The mitochondrial sidechain cleavage system is common to all steroid producing tissues and involves two cytochrome P-450 dependent hydroxylations of cholesterol at $\mathrm{C}_{20}$ and $\mathrm{C}_{22}$ followed by cleavage between $\mathrm{C}_{20}$ and $\mathrm{C}_{22}$. The hydroxylations are catalyzed by mixed function oxidases in a reaction requiring NADPH, molecular oxygen and cytochrome P-450. 20,22 dihydroxycholesterol is cleaved by a desmolase to yield C-21 pregnenolone and isocaproic acid.

Subsequent metabolism of pregnenolone to testosterone appears to require translocation of pregnenolone out of the mitochondrion and into the microsomal fraction of the leydig cell. However, the enzyme which converts pregnenolone to progesterone, 3B-Hydroxysteroid oxidoreductase, has been found in the mitochondria in rat adrenal preparations (7), 
and in rat testis $(8,9)$. In some species, it is possible that testosterone production may proceed from progesterone of mitochondrial origin, although it is generally presumed that the biosynthesis of testosterone proceeds from pregnenolone via steroidogenic enzymes associated with the smooth endoplasmic reticulum.

Biosynthesis of testosterone from pregnenolone may occur by either of two major pathways, the $\Delta_{4}$ pathway or the $\Delta_{5}$ pathway (Figure 1). The $\Delta_{5}$ pathway proceeds from prenenolone, a $\Delta_{\text {5-6 }}$ ene-3B-hydroxy steroid through $17 \alpha$-hydroxypregnenolone, Mehydroepiandrosterone and andostendiol to testosterone. The $\Delta_{4}$ pathway proceeds from pregnenolone to progesterone, a $\Delta_{4-5}$ ene-3-keto steroid and, subsequently, through $17 \alpha$-hydroxy progesterone and androstendione to testosterone. It has been reported that more than one pathway is utilized by the rabbit and the rat (10). These species demonstrate the use of mixed pathways which may proceed from PREG $\rightarrow 17$ PREG $\rightarrow$ DHEA $\rightarrow \mathrm{A} \rightarrow \mathrm{T}$ or from PREG $+17 \mathrm{PREG}+\mathrm{DHEA}+\frac{5}{5} \mathrm{DIOL}+\mathrm{T}$, or PREG $+17 \mathrm{PREG}+17 \mathrm{PROG}$ $A+T$. Since differences in testosterone production among species known to exist, it is possible that these differences may be accounted for by preferential use of the $\Delta_{4}, \Delta_{5}$ or mixed pathways.

Microsomal biosynthesis of testosterone from pregnenolone involves at least five enzymatic activities:

1) oxidation of the $c_{3}$ hydroxyl group to a ketone,

21 isomerization of the $\Delta_{5-6}$ double bond to the $\Delta_{4-5}$ position, 
32 17fhydroxylation,

4) side chain cleavage between $\mathrm{C}_{17}+\mathrm{C}_{19}$ and

5) reduction of the $\mathrm{C}_{17}$ ketone. The number of enzymes involved in catalysis of these reactions is controversial. Several possibilities are apparent. First, 3-BHSOR, which catalyzes the conversion of $\Delta_{5}$-hydroxysteroids to $\Delta_{5}$ ketone intermediates may exist as a single protein which accepts PREG, 17PREG, DHEA and ADIOL as substrate, or, multiple forms of the enzyme may exist, each with a specific substrate. Four isoenzymes of 3BHSOR have been reported in Pseudomonas testeroni (11) but not much evidence exists for mammalian forms. Evidence for a single 3BHSOR has been reported in the human adrenal (12), sheep adrenal cortex (13) and human testis (14). Secondly, the lyase and hydroxylase activities may exist as:

1) Four separate proteins, PREG lyase, PRO 1yase, PREG 17 $\alpha-$ Hydroxylase, PROG $17 \alpha$-Hydroxylase 2) two proteins, one being specific for PREG, the other for PROG, or, 3) one protein with both lyase and hydroxylase activities (with either one or two active sites). Lastly, testis 17-B Hydroxysteroid oxidoreductaseis believed to exist as at least two proteins, one which is product stimulated and one which is insensitive to $T$ (15), or, possibly, one for the forward reaction $A+T$ and a second enzyme catalyzing the oxidation of $T+A(16)$. However, pig testis 17BHSOR was found to purify as a homogeneous enzyme (17). 
It is necessary to determine the number of enzymes involved on steroid biosynthesis in order to predict the direction of the pathways. As suggested by Nakajin et al. (18), a single $17 \alpha$ Hydroxylase and lyase with one active site would not readily release the 17 ahydroxy product which is to serve as substrate for the lyase. This would, therefore, limit the use of mixed pathways. It is the purpose of this study to kinetically examine the steroidogenic pathways in two species, the rabbit and guinea pig and compare these data with kinetic data from the rat and dog to develop a kinetic model with which to predict the predominant pathway. 
METHODS AND MATERIALS

Experimental Animals

New Zealand white male rabbits (age 4-6 months) were obtained from a local source and used immediately. Male Hartley guinea pigs were purchased from Charles River Laboratories, wilmington, Massachusetts and maintained on rabbit chow (Agway, Kingston, Rhode Island), with an oral supplement of $10 \mathrm{mg}$. ascorbic acid per day. Water and feed were supplied ad libitum. Guinea pigs were purchased at 10 days of age, (150200 grams), and raised until they reached 42 days of age, (sexually immature), or to 100 days of age, (700-850 grams). Dog testes for the $\mathrm{C}_{17}-\mathrm{C}_{20}$ lyase experiment were obtained from a local animal hospital. The donor was a one-year-old retriever type dog who had been brought to the hospital for orchiectomy.

\section{Deparation of Microsomes}

Rabbits were sacrificed by injection of a $15 \mathrm{cc}$ air embolus into the ear vein. Guinea pigs were sacrificed by dislocation of the cervical vertebrae. Testes were quickly removed, placed on ice in .25M sucrose, decapsulated and weighed. Dog testes were obtained under general anesthesia, placed in .25M sucrose, kept on ice and transported to the laboratory within 1 hour of removal. Dog testes were decapsulated, weighed and minced in .25M sucrose, over ice, before homogenization. Tissues were homogenized in $(10 \% \mathrm{w} / \mathrm{V})$ ice cold .25M sucrose using a motordriven teflon pestle glass homogenizer. 
Microsomes were prepared by centrifugation at $1058 \mathrm{xg}$ for 10 minutes, the supernatant transferred and centrifuged $17,300 \mathrm{Xg}$ for 10 minutes and the resultant supernatant centrifuged $105,000 \mathrm{Xg}$ for 60 minutes. The microsomal pellet was resuspended in .25M sucrose using a hand-held glass homogenizer with a smooth teflon pestle. Protein was determined by the biuret method of Gornall (19).

\section{paration of Radioactive Substrates}

Pregnonolone-4- ${ }^{14} \mathrm{C}$, (S.A. $\left.55 \mathrm{mci} / \mathrm{mmole}\right), 17 a$-hydroxyregnenolone-7- ${ }^{3} \mathrm{H}(\mathrm{N}),(\mathrm{S} . \mathrm{A} .10 \mathrm{Ci} / \mathrm{mmole}$, and dehydroepianarosterone-4- ${ }^{14} \mathrm{C}$, (S.A. $55 \mathrm{mci} / \mathrm{mmole}$ ), were obtained from Amesham Corporation, Arlington Heights, Illinois. Progesterone-4- ${ }^{14} \mathrm{C}$, (S.A. $46 \mathrm{mci} /$ mmole), 17א-hydroxyprogesterone-4- ${ }^{14} \mathrm{C}$, (S.A. $50 \mathrm{mci} / \mathrm{mmole}$ ) and androstendiol-1,2-3H(N), (S.A. 45 $\mathrm{Ci} / \mathrm{mmol}$ ) were obtained from New England Nuclear, Boston, Massachusetts. Radiochemical purity of isotopes was confirmed by thin layer chromatography.

Non-radioactive steroids were obtained from Steraloids, Wilton, New Hampshire and Sigma Chemical Company, St. Louis, Missouri. Radioactive substrates for enzyme assays were prepared by diluting with a sufficient amount of non-radioactive steroid to achieve specific activities of: $4.44 \times 10^{7} \mathrm{dpm} / \mu \mathrm{mole}$ ( $\mathrm{c}^{14}$-pregnenolone), $1.08 \times 10^{9} \mathrm{dpm} / \mu \mathrm{mole}$ (DHEA), $4.28 \times 10^{8} \mathrm{dpm} /$ umole (androstendiol), $4.06 \times 10^{7} \mathrm{dpm} / \mu$ mole (progesterone) and 3. $52 \times 10^{7} \mathrm{dpm} /$ mole (17a-hydroxyprogesterone). 
Pazyme Incubations

Microsomal protein $(60-250 \mu \mathrm{g})$ was incubated with radioactive substrate (1-40 $\mu \mathrm{M})$ in 18 propylene glycol, $500 \mu \mathrm{M}$ NAD, (Sigma Chemical Co., St. Louis, Missouri), or, NADPH, (Schwartz-Mann, Orange, New Jersey), as indicated, .1M Tris, $\mathrm{pH} 7.4$ and $5 \mathrm{mM} \mathrm{MgCl}_{2}$ in a final volume of $.1 \mathrm{ml}, \Delta_{5}$ lyase and hydroxylase reactions were measured in the presence of $5 \mu \mathrm{g}$ cyanoketone (Sterling-Winthrop Research Institute, Rensselaer, New York), to prevent conversion to $\Delta_{4}$ products. Protein was added to initiate the reaction. Tubes were incubated $37^{\circ} \mathrm{C}$ in a reciprocating water bath for 5 minutes, (10 minutes for lyase and hydroxylase reactions, where indicated). The microassay was designed so that the amount of product produced remained well below the $\mathrm{K}_{0.5}$ for the subsequent reaction. In this manner, a single reaction product was measured in most assays.

Enzyme reactions were terminated with $.3-.4 \mathrm{ml}$ cold methanol containing appropriate carrier steroids for visualization after thin layer chromatography $\left(50 \mu \mathrm{g} / .4 \mathrm{ml}\right.$ of $\Delta_{4}$ 3-keto-steroids and $200 \mathrm{\mu g} / .4 \mathrm{ml}$ of $\Delta_{5}$ 3-hydroxysteroids). Tubes were covered immediately and kept frozen $\left(-5\right.$ to $\left.-15^{\circ} \mathrm{C}\right)$ until separation by TLC.

\section{Aation and Identification of Steroids}

One half the volume from each incubtion tube was placed on a $5 \times 20 \mathrm{~cm}$ silica gel HLF plate (Analtech, Inc., Newark, Delaware). Each plate was developed in acetone three times, 
drying thoroughly between each application, to a point $1.5 \mathrm{~cm}$ above the origin. The product and substrate were separated in jar-type TLC tanks lined with whatman \#l chromatography paper to promote saturation. Elutropic solvents (20) were used for separation as follows:

1. PROG/17aPROG

2. PREG/17 $\propto$ PREG

3. PREG/PROG

4. 17 $\alpha$ PREG/17 $\alpha$ PROG

5. DHEA/A

6. $\mathrm{ADIOL} / \mathrm{T} / \mathrm{A}$

7. 17 $\propto$ PREG/DHEA

8. $17 \alpha \mathrm{PROG} / \mathrm{A}$
- dichloromethane:butylacetate (2 developments)

- benzene: acetone

- chloroform:ethyl acetate

- benzene:acetone

- benzene:acetone

- benzene:acetone

- (1) dichloromethane:ethylacetate 9:1

(2) chloroform: diethylether

- (1) dichloromethane:ethylacetate 9:1 (2) chloro form: diethylether
$9: 1$

$4: 1$

$3: 1$

$4: 1$

$4: 1$

$4: 1$

$4: 1$

$4: 1$

All solvents were chromatographic grade or better. Separated $\Delta_{5}-3$ hydroxysteroids were detected by exposure to iodine vapor and $\Delta_{4}-3$ ketosteroids were detected by UV fluorescence (254 nm) . Steroids were identified by $R_{f}$ value and verified by standards run in the same solvent system.

\section{itufication of Product}

The product band was scraped from the TLC plate and the silica gel containing radioactive steroid was added directly to a liquid scintillation vial (New England Nuclear, Boston, Mass.), to which $7 \mathrm{ml}$ Bray's scintillation Cocktail (New England Nuclear, Boston, Mass.) was added. Radioactivity was counted in a Packard TRI-CARB Liquid scintillation spectrometer 
(Packard,Downer's Grove, Illinois). Efficiency of counting was determined by using the External Standards Ratio method and found to be 48-50\% for $\mathrm{H}^{3}$ and $83-84 \%$ for $\mathrm{C}^{14}$.

\section{Dochrome P-450 Determination}

Cytochrome $\mathrm{P}-450$ was measured in testis microsomes using a Cary 15 split beam spectrophotometer, (Applied Physics Corp., Monrovia, Calif.), modified with a high intensity light source as described by Menard and Purvis (21). Incubations consisted of $1-4 \mathrm{mg} / \mathrm{ml}$ microsomal protein in .1M Tris, pH 7.4. Difference spectra were obtained by measuring absorbance of dithionite/CO minus $\mathrm{CO} / \mathrm{CO}$ at $450 \mathrm{~nm}$. The extinction coefficient for changes in absorbance between $450-490 \mathrm{~nm}$ is assumed to be $100 \mathrm{~cm}^{-1} \mathrm{~nm}^{-1}$.

\section{DISCUSSION OF METHODS}

The enzyme assays were designed to measure one product.

1) 3BHSOR reactions were inhibited by cyanoketone for measurement of only $\Delta_{5}$ product in preg-hydroxylase and lyase reactions.

2) Absence of appropriate cofactor, (NADPH) prevented synthesis of hydroxylated product in PREG $\rightarrow$ PROG reactions.

3) The $\Delta_{4}$ and $\Delta_{5}$ hydroxylations were run under conditions such that the product was produced at a rate much below the $k_{0.5}$ for the lyase reactions. While it is known that internally generated substrate may be better utilized than substrate which is added externally, small amounts of product generated in this system did not act as substrate for 
the lyase reactions. Only two radioactive bands could be detected in the hydroxylase assays corresponding to product and substrate. This may be attributable to the strong inhibition of the lyase by PROG which has been demonstrated by Purvis et al. 9

4) The $\Delta_{4}$ lyase reaction has been shown to produce only androstendione and the $\Delta_{5}$ lyase consistently produces only DHEA using this assay system. No radiolabeled 17-hydroxysteroid product bands appear when cold $T$ and ADIOL are added as carrier steroids at the termination of these reactions.

5) The only case in which more than one product is formed from a reaction is the ADIOL $\rightarrow T$ reaction in which both ADIONE and $T$ are measured to quantitate the total product of the 3BHSOR reaction. Under the assay conditions the production of ADIONE from the product T, (17B-hydroxysteroidoxidoreductase reaction), remains small. 


\section{RESULTS}

MICROSOMAL ENZYME ACTIVITY

Rinetic data from rabbit and guinea pig testis microsomes is summarized in TABLE 1 . Michaelis constants $\left(\mathrm{k}_{0.5}\right)$ and $\mathrm{V}_{\max }$ were estimated by the graphic method of Lineweaver-Burk (22). The $k_{0.5}$ for PREG in the 3 BHSOR reaction was found to be three times higher in the rabbit than in the guinea pig (Figure 2). However, $k_{0.5}$ for $17 \alpha \mathrm{PREG}$ and DHEA (Figures 3-4) were lower in the rabbit than in the guinea pig. This relative change in affinity for $\Delta_{5}$ substrates is attributable to the decreased $k_{0.5}$ in the rabbit and increase in the $k_{0.5}$ in the guinea pig for $17 \alpha \mathrm{PREG}+\mathrm{DHEA}$ with respect to $\mathrm{k}_{0.5}$ PREG. The $\mathrm{k}_{0.5}$ for ADIOL was identical in the rabbit and guinea pig (Figure 5). The $V_{\text {max }}$ of the PREG $\rightarrow$ PROG reaction was six times greater in the guinea pig than in the rabbit (Figure 2) and similar in the $17 \alpha \mathrm{PREG}+17 \alpha \mathrm{PROG}$ reaction (Figure 2 ). The $\mathrm{V}_{\max }$ in the guinea pig DHEA $\rightarrow \mathrm{A}$ and $\mathrm{ADIOL}+\mathrm{T}$ reactions were nearly identical (Figure 4-5) and these velocities were $50 \%$ of those obtained with PREG as substrate. The highest 3BHSOR activity in the sexually mature rabbit was obtained with ADIOL (Figure 5), although data from TABLE I would suggest that the 17aPREG: 3BHSOR reaction is the most active. Testis microsomes for the $17 \alpha$ PREG $\rightarrow 17 \alpha$ PROG reaction were obtained from a 4 month old rabbit. Prior to sexual maturation ( 6 months of age in the rabbit), the amount of interstitial, (Leydig cells), enzyme 
is higher on a milligram protein basis due to the absence of fully developed tubules. When the apparent $V_{\max }$ of the 17 aPREG +17 aPROG reaction is corrected per $\mathrm{nm} P-450$, the $\mathrm{V}_{\max }$ is lower (TABLE III) and the ADIOL $\rightarrow T$ reaction is oberved to be the most active.

The $A D I O L \rightarrow T$ reaction is linear in the guinea pig at low protein concentrations (Figure 6). High protein concentrations were necessary to saturate the enzyme before kinetic constants could be determined.

Large differences in the Michaelis constants of the $17 \alpha$ hydroxylase reaction for PREG were noted between the rabbit and guinea pig (Figure 7). Although the $k_{0.5}$ for the $\Delta_{5}$ substrate was greater than the $k_{0.5}$ for $\Delta_{4}$ progesterone in both instances, the ratio of $\mathrm{k}_{0.5}$ PREG/PROG was found to be 20 in the guinea pig as compared to 3.3 in the rabbit. The $v_{\max }$ for the 17 -hydroxylase reaction with $\Delta_{5}$ and $\Delta_{4}$ substrates were similar in the rabbit (Figures 7-8), whereas, the velocity with progesterone was 9.6 times greater than with pregnenolone in the guinea pig.

$\mathrm{C}_{17}-\mathrm{C}_{20}$ lyase activity could not be detected in the guinea pig with 17aPREg as substrate nor in the rabbit with $17 \alpha$ PROG as substrate. PROG:lyase in the guinea pig was found to have the lowest $k_{0.5}$ of any of the enzymes studied (Figure 9). The $V_{\max }$ in the $17 a \mathrm{PROG}+\mathrm{A}$ reaction in the guinea pig was 258 of the velocity of the preceding $\Delta_{4}$-hydroxylase re action. In the rabbit the Michaelis constant of the PREGlyase reaction (Figure 10) was lower than that of the PREG- 
hydroxylase and the $\mathrm{v}_{\max }$ values were similar. CYTOCHROME P-450 DETERMINATIONS

TABLE II summarizes cytochrome P-450 levels of testis microsomes. Cytochrome P-450 levels have been shown to reflect the hydroxylase and lyase activities of the microsomes (23). Since the Leydig cell volume and $\&$ Leydig cells varies so greatly among species, it is difficult to compare enzymatic activity on a milligram protein basis. Therefore, cytochrome $\mathrm{P}-450$ values have been used as a constant upon which to express relative enzyme activities.

COMPARISON OF MICROSOMAL ENZYME ACTIVITY IN FOUR SPECIES Enzyme activities for four species were expressed as $\mathrm{nm}$ product/min/nm P-450. TABLE III summarizes the kinetic data for 3BHSOR activities on the rabbit, guinea pig, dog (24) and rat (24) testis microsomes. The $\mathrm{k}_{0.5}$ for PREG in the dog is twenty times higher than the guinea pig enzyme. The rabbit and rat have similar $k_{0.5}$ for PREG and these values are intermediate with respect to the dog ( 7 to 8 times lower), and guinea pig, (2.5 times higher). The $\mathrm{V}_{\text {max }}$ for the PREG + PROG reaction, on a $\mathrm{P}-450$ basis, is the greatest in the rat and lowest in the dog. The $v_{\max }$ for this reaction in the rabbit and guinea pig are intermediate, with the guinea pig value determined to be twice as great as the rabbit and $33 \%$ of the rat activity. Michaelis constants of the $17 \alpha$ PREG $\rightarrow 17_{\alpha}$ PROG reaction are similar in the rat, rabbit and guinea pig and 
high in the dog. The $\mathrm{V}_{\max }$ of the $17_{\alpha}$ PREG $\rightarrow 17$ PROG reaction parallel the $\mathrm{V}_{\max }$ of $\mathrm{PREG} \rightarrow \mathrm{PROG}$ in the rabbit, guinea pig and rat, although this 3BHSOR activity is the lowest demonstrated in the dog. It is interesting to note that where the $k_{0.5}$ for 17APREG + DHEA are decreased in the rabbit with respect to the $k_{0.5}$ for PREG, the values are increased in the guinea pig and remain fairly constant in the rat. The $k_{0.5}$ for DHEA in the dog is the lowest demonstrated for that species, although the $\mathrm{V}_{\max }$ of the reaction is low, The $\mathrm{V}_{\max }$ of the DHEA $\rightarrow$ A reaction is the highest of the 3BHSOR activities in the rat. The ADIOL $\rightarrow T$ reaction is the most unusual of the 3BHSOR activities. The highest $v_{\max }$ for $3 B H S O R$ in the rabbit and dog is obtained with ADIOL as substrate although the $k_{0.5}$ for ADIOL in both instances is higher than the $k_{0.5}$ for DHEA. The rat $k_{0.5}$ for ADIOL is the lowest of the $\Delta_{5}$ substrates and the $v_{\max }$ is 23-30\% of the values obtained with the other $\Delta_{5}$ substrates. The $k_{0.5}$ for ADIOL in the guinea pig is similar to $k_{0.5}$ for DHEA and $17 \alpha$ PREG and the $v_{\max }$ is the lowest demonstrated for any of the 3BHSOR substrates.

The kinetic data for the $17_{\alpha}$ hydroxylase and $\mathrm{c}_{17}-\mathrm{C}_{20}$ lyase reactions is summarized in TABLE IV. The $k_{0.5}$ for PREG in all species was greater than the $k_{0.5}$ for PROG in the hydroxylase reaction and the $\mathrm{v}_{\max }$ of the PROG $\rightarrow 17$ PROG reaction was higher than for PREG $\rightarrow 17 \alpha$ PREG in all but the dog. Each species demonstrated both PREG and PROG hydroxylase activity. The rat is the only species which possesses both PREG and PROG lyase activities. In the rabbit and dog microsomal $\Delta_{4}$ lyase 
activity was not detected. In contrast, no $\Delta_{5}$ lyase activity was detectable in the guinea pig.

Since PROG-Iyase activity had been previously reported in the rabbit (25), an experiment was conducted to examine the possibility that a cytosolic $\Delta_{4}$ lyase existed in dog and rabbit testes. The 105,000Xg supernatant of dog testis was found to have a small but measurable, amount of $\Delta_{4}$ lyase activity. The enzyme demonstrated a dual specificity for NADH and NADPH although better activity was obtained with NADH. The Michaelis constant of the NADH-cytosolic $\mathrm{C}_{17}-\mathrm{C}_{20}$ lyase for PROG was $20 \mu \mathrm{M}$ and the $\mathrm{V}_{\max }$ of the reaction was determined to be $2 \mathrm{~mm} / \mathrm{min} / \mathrm{nm} \mathrm{P}-450$. No cytosolic $\Delta_{4}$ lyase activity could be detected in the rabbit $105,000 \mathrm{Xg}$ supernatant. It is possible that the failure to detect this activity in the rabbit is attributable to the stage of sexual development, as the animal used in this experiment was four months of age. No microsomal $\Delta_{4}$ lyase activity could be detected in the presence of $500 \mathrm{MM} \mathrm{NADH}$ in either the rabbit or the dog. 


\section{DISCUSSIONS AND CONCLUSIONS}

The synthesis of testosterone from pregnenolone has been shown to proceed by the $\Delta_{4}$ pathway $(26,27,28)$ and the $\Delta_{5}$ pathway $(29,30,31,32)$ in several mammalian species. Enzymatic activities of these pathways were determined and are presented in Figure 11. The kinetic data is a useful predictor of the $\Delta_{4}$ or $\Delta_{5}$ pathway in testosterone biosynthesis. The key step in determining the direction of the pathway is the conversion of PREG to PROG, $\left(\Delta_{4}\right)$, or to $17 \alpha$ PREG, $\left(\Delta_{5}\right)$. The most definitive kinetic predictors of the $\Delta_{4}$ or $\Delta_{5}$ pathway were found to be 1) the Michaelis constant of the 3BHSOR reaction for PREG and, 2) the $V_{\max }$ of the PREG-17ahydroxylase reaction. The affinity of $3 B H S O R$ for $P R E G,\left(k_{0.5}=2.5 \mathrm{M}\right)$, in the guinea pig as constrasted to the high $\mathrm{k}_{0.5}{ }^{\prime}(50 \mu \mathrm{M})$, in the dog, suggests predominant use of the $\Delta_{4}$ pathway by the guinea pig and $\Delta_{5}$ pathway in the dog. The Michaelis constants of the 3BHSOR reaction for PREG on the rat, $(6 \mu \mathrm{M})$, and rabbit $(7 \mu \mathrm{M})$ are intermediate and suggest the use of mixed pathways. This prediction is strengthened by the low $v_{\max }$ of the PREG-17 $\alpha-$ hyaroxylase reaction in the guinea pig and the extensive activity of this enzyme in the dog. The $v_{\max }$ of the $\Delta_{5} 17 \alpha-$ hydroxylase reactions in the rat and rabbit are, again, intermediate, suggestive of mixed pathways although favoring the $\Delta_{4}$ in the rat and $\Delta_{5}$ in the rabbit. 
The ratio of the Michaelis constants for PREG in the 3BHSOR and 17 -hydroxylase reactions (TABLE V) provides further information with which to predict the predominant pathway under conditions of submaximal stimulation where PREG is unlikely to be saturating. In the dog, $1 / 2 \mathrm{v}_{\max }$ for the hydroxy.lase reaction would be reached at substrate concentrations $50 \%$ lower than the $k_{0.5}$ for the 3 BHSOR reaction. Since the $v_{\max }$ of the hydroxylase reaction is 5 times greater, most of the PREG would be metabolized to 17 aPREG. In the guinea pig, $1 / 2 \mathrm{v}_{\max }$ will be reached for the 3BHSOR reaction at PREG concentrations which are 108 of the $k_{0.5}$ for the hydroxylase and metabolism of PREG to PROG would occur at a rate at least 32 times greater than the conversion of PREG $\rightarrow 17$ PREG. The Michaelis constants and $v_{\max }$ for PREG in the 3BHSOR and $17 \alpha$-hydroxylase reactions are identical in the rabbit and it is probable that $50 \%$ of the substrate would be metabolized to PROG and $50 \%$ would be converted to $17 \alpha$ PREG. Although the Michaelis constants of the two reactions are similar in the rat, the $v_{\max }$ is 30 times greater for the 3BHSOR reaction and most of the PREG would be expected to be metabolized to PROG.

Since PROG is a known inhibitor of 3BHSOR activity, it becomes necessary to verify predictions by examining the rate of removal of PROG (TABLE VI). The Michaelis constants for the hydroxylase are of little use for this purpose as small variation on $k_{0.5}$ for PROG was noted and since the $k_{0.5}$ for PROG were lower than $k_{0.5}$ for PREG in each species. The ratio of $k_{0.5}$ PROG/PREG may be used to demonstrate the relative 
affinity of the hydroxylase for $\Delta_{4}$ and $\Delta_{5}$ substrates in the guinea pig, rat and rabbit. This ratio is misleading in the dog because the $k_{0.5}$ for PREG is large for both the $\Delta_{5}$ hydroxylase and the 3 BHSOR reactions. However, the $k_{0.5}$ for PROG in the hydroxylase reaction is consistent with data from Eik-Nes (33) demonstrating rapid conversion of PROG to $17 \alpha$ PROG in dog testes and the appearance of $17 \alpha \mathrm{PROG}$ as a secretion product in this species. The ratio of hydroxylase activity on a $v_{\max }$ basis is a useful indicator of the relative disappearance of PROG via the $\Delta_{4}$ pathway and PREG via the $\Delta_{5}$ pathway. $\quad \Delta_{4}$ 17-hydroxylase activity is 10 times greater than $\Delta_{5}$ hydroxylase activity in the guinea pig and 5 times higher in the rat. This comparison strengthens the prediction since 3BHSOR activity in $\Delta_{4}$ animals is dependent upon an adequate rate of removal of PROG. The ratio of $\Delta_{4} / \Delta_{5}$ hydroxylase activity in the dog shows the reaction velocity at saturation to be 8.3 times greater in the $\Delta_{5}$ pathway.

The kinetic data from the rabbit presents somewhat of a problem. Similar $k_{0.5}$ and $v_{\max }$ values for PREG in the 3BHSOR and hydroxylase reactions and the ratio of $v_{\max }$ PROG/PREG suggest that the rabbit may use either the $\Delta_{4}$ or the $\Delta_{5}$ pathway for testosterone production. This appears to be true for $17 \alpha$ PROG synthesis as the $k_{0.5}$ for the PREG $\rightarrow 17 \alpha$ PROG reaction is low in the rabbit and the $v_{\max }$ is similar to the PREG3BHSOR activity but the rabbit testis microsomes do not possess detectable $\mathrm{C}_{17}-\mathrm{C}_{20}$ lyase activity with PROG as substrate. 
Therefore, the $\Delta_{4}$ pathway to $T$ would be blocked in this species. The absence of $\Delta_{4}$ lyase activity in dog testis microsomes fully supports the prediction that the $\Delta_{5}$ pathway is the route to $T$ production in the dog. The demonstration of a NADH-linked form of the enzyme is interesting although the high $k_{0.5}$ and low $v_{\max }$ of this enzyme would result in the production of very little A for testosterone synthesis. The failure to detect $\Delta_{5}$ lyase activity in guinea pig testis microsomes may be presented as further evidence that the guinea pig uses the $\Delta_{4}$ pathway for testosterone synthesis.

These kinetic predictions regarding the direction of the steroidogenic pathway are in agreement with other in vitro data showing that the rat (27) and guinea pig (28) uses the $\Delta_{4}$ pathway and that the dog (30) uses the $\Delta_{5}$ pathway for testosterone synthesis. In vivo perfusion techniques developed by Chubb and Ewing (34) and using specific enzyme inhibitors to block multi-directional pathways (10) have demonstrated that the dog and rabbit secrete primarily $\Delta_{5}$ steroids and the guinea pig (35) and rat secrete mainly $\Delta_{4}$ steroids. In these studies, no 170PREG was detectable in guinea pig testes secretions. This is in agreement with the present finding that the PREG-hydroxylase activity is very low in guinea pig testes nicrosomes.

An alternate pathway from PREG $\rightarrow 17 \alpha \mathrm{PREG} \rightarrow 17 \alpha \mathrm{PROG} \rightarrow \mathrm{A} \rightarrow \mathrm{T}$ was proposed for the rat based on secretion studies. This is compatible with the kinetic data for PREG-hydroxylase and 3BHSOR activity for PREG in rat testis microsomes. However, 
one difference exists between the kinetic data and the perfusion studies. Chubb and Ewing (10) have demonstrated that the rabbit produces a small amount of androstendione in the presence of medrogestone, an inhibitor of 3BHSOR activity. One major difference between the kinetic and the perfusion studies is that the kinetic studies use microsomes from whole testis and perfusion studies use the whole testis. If the rabbit has a soluble lyase such as that seen in the dog, the difference could be explained.

Although the kinetic studies allow for the synthesis of androstendione from DHEA in the rabbit, the presence of inhibitor suggests that androstendione must have been produced from infused $17 \alpha P R O G$ in the perfusion study and not from endogenous DHEA. The fact that the testes were under LH stimulation during the perfusion is of little consolation. Presumably, this short term stimulation with high doses of LH maximizes the flux by releasing inhibition on the cholesterol side chain cleavage enzymes. IH stimulation for 4.5 hours would not be expected to stimulate protein synthesis so the appearance of $\Delta_{4}$ lyase activity cannot be explained on the basis of increased enzyme synthesis. Data from van der Molen et al. (25) suggests one possible explanation for the contrasting data. 17aPROG was shown to be converted to androstendiol in the $800-105,000 \times \mathrm{g}$ pellet of a rabbit testis homogenate suggesting that the $\mathrm{C}_{17}-\mathrm{C}_{20}$ lyase activity may be associated with the mitochondria which would obviously have been present in this pellet. The present findings can neither confirm nor reject this possibility. 
The kinetic data for $17 \alpha$-hydroxylase and lyase activity in testis microsomes suggests that the $\Delta_{5}$ and $\Delta_{4}$ hydroxylases and lyases are four distinct enzymes. In support of this hypothesis, is the 25 fold difference in Michaelis constants of the hydroxylase reaction for $\Delta_{5}$ and $\Delta_{4}$ substrates in guinea pig testis microsomes. All $\mathrm{k}_{0.5}$ for the hydroxylase were shown to be greater for PREG, yet the dog enzyme demonstrated 6.7 times higher activity for the high $\mathrm{k}_{\mathrm{m}}$ form of the enzyme. The existence of more than one $\mathrm{C}_{17}-\mathrm{C}_{20}$ lyase activity in the testes has been demonstrated by the cytosolic NADH-activated enzyme in the dog. Differing $v_{\max }$ values of the microsomal lyase with respect to PROG and PREG in the rat suggest that these activities are associated with different enzymes. The absence of $\mathrm{C}_{17}-\mathrm{C}_{20}$ lyase activity with $\Delta_{4}$ substrate in the dog and rabbit and nondetectable $\Delta_{5}$ lyase activity in the guinea pig should be considered as evidence that two lyases exist and the demonstration of $\Delta_{4}$ hydroxylase activity in the dog and rabbit and weak $\Delta_{5}$ hydroxylase activity in the guinea pig shows that the lyase activity is not necessarily associated with the same protein as the hydroxylase. However, a purified cytochrome P-450 which possesses both hydroxylase and lyase activity has been isolated from testis microsomes in the neonatal pig (36). This purified enzyme was shown to consist of one subunit by electrophoretic and immunochemical criteria. This data is not conclusive since membrane bound enzymes often appear to be homogeneous by these criteria dueto the hydrophobic nature of the proteins which causes them to associate and migrate together 
in an electric field, Further evidence (10) was obtained for bomogenicity of the neonatal pig cytochrome by temperature $\mathrm{pH}$ optimum, denaturation and inhibition studies. The enzyme was shown to possess one heme molecule which suggests one active site. Although the data is consistent with the one active site model of Hochberg et al. (37), this group's own data presents evidence against one active site for lyase and hydroxylase activities. First, the activity of the hydroxylase and lyase exist in a 1,8:1 stoiciometry. Second, the Michaelis constants for the hydroxylase and lyase activities are different, suggesting more than one binding site, and lastly, certain activators which stimulate the hydroxylase activity were unable to stimulate the lyase reaction. Other evidence against one active site was presented by Samuels and Matsumoto (38) who were able to demonstrate an exchange between exogenous $17 \alpha$ PROG and the enzyme bound intermediate generated from PROG, suggesting movement of 17aPROG from one site to another. The presence of one heme is also in contrast to finding in rat testis microsomes (39) that different cytochromes were involyed in hydroxylase and lyase activities.

Table VII summarizes the ratio of lyase to hydroxylase activity in the rat, guinea pig, dog and rabbit. The ratios suggest independent synthesis of hydroxylase and lyase. It appears that these activities may exist as two subunits that associate to form a 1:1 dimer, a 2:1 dimer, or, as 2:1 dimers plus free hydroxylase. The activity of the free hydroxylase 
is assumed to be higher as steric hinderance would exist in the dimeric form. This would easily account for the $1: 1.1$ stociometry demonstrated in the rabbit. Studies on postnatal development of microsomal enzyme activity in rat testes (40) also suggests independent synthesis of hydroxylase and lyase. Between 23-32 days of postnatal development, hydroxylase and lyase activities exist in a $1: 1$ ratio with maximum $\mathrm{C}_{17}-\mathrm{C}_{20}$ lyase activity occurring at 32 days. At 32 days the ratio of the rate of synthesis of hydroxylase lyase becomes 2.2 . In all probability, this increased rate of synthesis of the hydroxylase represents the transition from $1: 1$ stoiciometry to the 1:2 dimer. Additionally, the hydroxylase activity does not reach maximal until 40 days, demonstrating independent synthesis of this enzyme. Different rates of synthesis under stimulation by gonadotrophic hormones was demonstrated by Latif and Purvis (41). The rate of synthesis of hydroxylase/lyase in the pypophysectomized rat was 2.44 under stimulation by LH, FSH and GH.

The ratio of hydroxylase to lyase activities shows an excess amount of $\Delta_{5}$ hydroxylase on the dog and an excess amount of $\Delta_{4}$ hydroxylase in the rabbit and guinea pig. The activity of PROG hydroxylase on a milligram protein basis is fairly constant in the 4 species $(.2 \mathrm{~nm} / \mathrm{mg} / \mathrm{min}$ in the rat, $.24 \mathrm{~nm} / \mathrm{mg} / \mathrm{min}$ in the guinea $\mathrm{pig}, .159 \mathrm{~nm} / \mathrm{mg} / \mathrm{min}$ in the rat and $.12 \mathrm{~nm} / \mathrm{mg} / \mathrm{min}$ in the dog). These values are in agreement with Menard, Stripp and Gillette (42), showing no more than a 2-fold difference in hydroxylase activity. It appears that the excess amount of 
hydroxylase is involved in the control of testosterone production by the gonadotrophic hormones. It is well accepted that the rate limiting step in testis steroid synthesis, under low LH concentrations, is the side chain cleavage of cholesterol. Stimulation with high levels of LH for long periods of time is known to stimulate protein synthesis resulting in increased amounts of 17 -hydroxylase and $c_{17}-c_{20}$ lyase. The lyase has been shown to be more sensitive to low concentrations of LH than the hydroxylase (41) and under these conditions one could easily increase testosterone production by stimulating lyase synthesis in the presence of excess hydroxylase. Whereas high LH levels stimulate the synthesis of the hydroxylase to a greater extent than the lyase (41), the hydroxylase is more susceptible to desensitization by high LH.

Others have suggested that the opposite lyase, the $\Delta_{5}$ lyase in the rat (43) and the $\Delta_{4}$ lyase in the human (44) is the rate limiting step in testosterone production. The kinetic analysis of the steroidiogenic enzymes in the dog, rat, rabbit and guinea pig does not preclude this hypothesis. The human testis is thought to be under periodic LH stimulation. It is possible that under long-term, maximal, LH stimulation the opposite lyase and hydroxylase may be synthesized and, in thismanner, release inhibition on testosterone synthesis by increasing the number of alternate pathways. 


\section{References}

1. Hall, P.F., Nishizowa, Z.Z. and Eik-Nes, K.B. (1963) Proc. Soc. Expt1. Biol. Med. 114, 791.

2. Hall, P.F. (1966) Endocrinology $\underline{76}, 396$.

3. Sulimovici, S. and Boyd, G.S. (1968) Eur. J. Biochem 2, 232.

4. Halkerson, I.D.E., Eichors, J., Heckter, O. (1971) J. Biol. Chem. 263, 374 .

5. Tamaoki, B. and Pincus, G. (1961) Endocrinology 64, 527.

6. Hall, P.F. and Koritz, S.B. (1964) Biochem. 3, 129.

7. Basch, R.S. and Finegold, M.J. (1971) Biochem. J. 125, 983.

8. Sulimovici, S., Bartoov, B. and Lunenfeld, B. (1973) Biochem. Biophys. Acta 321;, 27.

9. Purvis, J.L., Personal Communication.

10. Chubb, C. and Ewing, L.L. (1979) Am. J. Physiol. 237, E247.

11. Schultz, R.M., Groman, E.V. and Engel, L.L. (1977) J. Biol. Chem. 252, 3775.

12. Yates, J. and Deshpande, N. (1975). J. Endocrinology 64 . 195.

13. Ford, H.C. and Engel, L.L. (1974). J. Biol. Chem. 294, 1363 .

14. Oshima, H., Fan, D. and Troen, P. (1975). J. Clin. Endocrinol. Metab. $40,573$.

15. May, J.V., Hologgitas, J. and Purvis, J.L. (1978) Fed. Proc. 37, 1474 .

16. Bogovich, K. and Payne, A.H. (1978) Fed. Proc. 37, 1579.

17. Inano, H. and Tamaoki, B. (1974) Eur. J. Biochem. 44, 13.

18. Nakajin, S., Shively, J.Z., Yuan, P. and Hall, P.F. (1981) Biochem. 20, 4037 .

19. Gornall, A.G., Bardavill, C.J., David, M.M., J. Biol. Chem. (1949) $177,757$. 
20. Trappe, W. (1980) Biochem. Z. 305, 150 .

21. Menard, R.H. and Purvis, J.L. (1973) Arch. Biochem. Biophys. 154,8 .

22. Lineweaver, H. and Burk, D. (1934) J. Am. Chem. Soc. 56, 658.

23. Purvis, J.L., Canick, J.A., Latif, S., Rosenbaum, J.H., Hologgitas, J. and Menard, R.H. (1973) Arch. Biochem. Biophys. 159,39 .

24. Hologgitas, J.V. (1981). Ph.D. Dissertation. University of Rhode Island, Kingston.

25. Van der Molen, H.J., de Bruijin, H.W.A., Cooke, B.A., deJong, F.H. and Rommerts, F.F. (1973) In: The Endocrine Function of the Human Testis, Vol. 1, ed. by James, V.H.T., 10, M. and Martini, L. New York: Academic Press.

26. Slaunwhite, W.R. and Samuels, L.T. (1956). J. Biol. Chem. 220, 341 .

27. Shikita, M., Kakizaki, H. and Tamaoki, B. (1964). Steroids $\underline{4}, 521$.

28. Gower, D.B. and Hazelwood, G.D.A. (1961) J. Endocrinol. $\underline{23}, 253$.

29. Neher, R. and Wettstein, A. (1961) Acta Endocrinol. 35, 1.

30. Eik-Nes, K.B. and Kekre, M. (1963). Biochim. Biophys. Acta $\underline{78}, 449$.

31. Rosner, S.M., Horitz, S. and Forsham, P.H. (1964). thocrinology 75, 229.

32. Slaunwhite,W.R. and Burgett, M.J. (1965) Steroids $\underline{6}$, 721.

33. Eik-Nes, K.B. (1970) In: The Androgens of the Testis ed. by K.B. Eik-Nes, New York: Dekker, p. 10.

34. Chubb, C. and Ewing, L.L. (1979) Am. J. Physiol. 237, E239.

35. Ewing, L.L., Cochran, R.C., Zirkin, B. and Chubb, C.E. $(1980)$. In: Testicular Development, Structure and Function, ed. by steinberger, A. and Steinberger, E., New York: Raven Press, p. 117.

36. Nakajin, S. and Hall, P.F. (1981) J. Biol. Chem. 256, 3871. 
37. Hochberg, R., Landany, S., Lieberman, E.S. (1976) J. Biol. Chem. 251, 3320 .

38. Samuels, L.T. and Matsumoto, K. (1974) Endocrinology 94 , 55.

39. Betz, G.,Tsai, D. and Hales, D. (1980) Endocrinology 107, 1055 .

40. Jiminez, U. (1975) Ph.D. Dissertation. University of Rhode Island, Kingston.

41. Letif, S.A. and Purvis, J.L., unpublished data.

42. Menard, R., Stripp and Gillette (1974) Endocrinology 94, 1628 .

43. Knapstein, P., Wendleberger, F., Menzel, P., Oertel, G. and Touchstone, J.C. (1968) steroids 12, 191.

44. Yahaihara, T. and Troen, P. (1972). J. Clin. Endocr. 34, 783. 
Figure 1. Steroidogenic pathways in mammalian testis microsomes. 


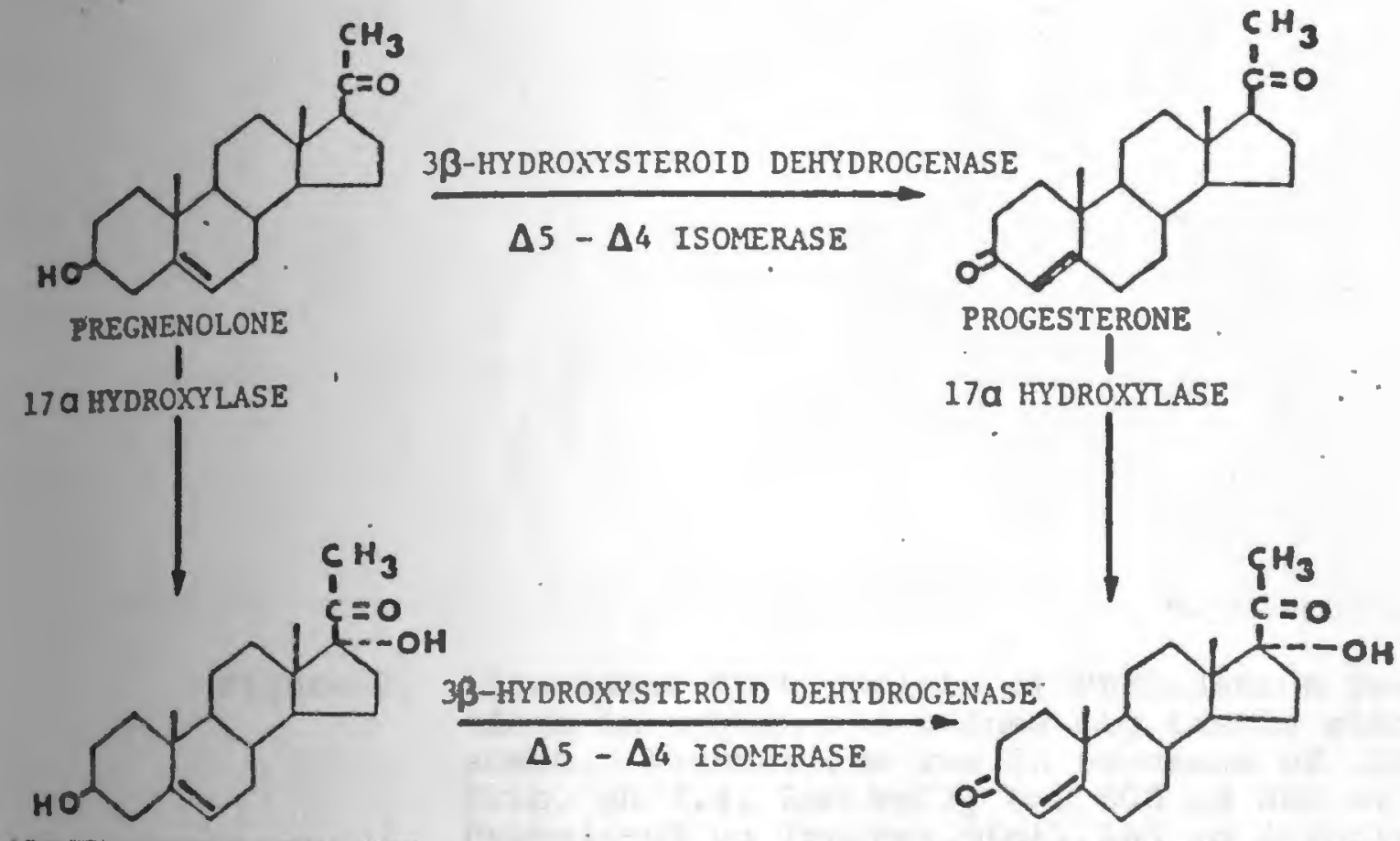

170 WOROXYPREGNENOLONE
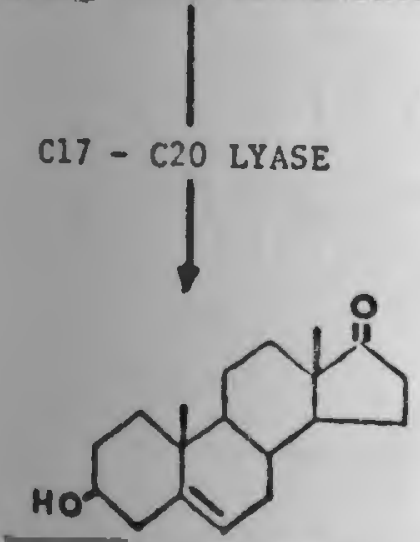

PLANDROSTERONE

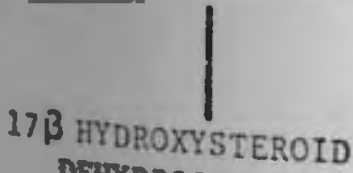

DATPROGENASE

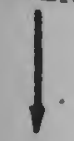<smiles>CC12CCC3C(CC=C4CCCC[C@@]43C)C1CC[C@H]2O</smiles>

$3 \beta$-HYDROXYSTEROID DEHYDROGENASE
$3 \beta=$ HYDROXYSTEROID DEHYDROGENASE $\Delta 5-\Delta^{\prime}$ ISOMERASE
17 a HYDROXYPROGESTERDIE



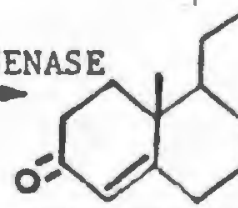

ANDROSTENEDIONE

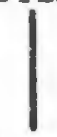

$17 \beta$ HYDROXYSTEROID DEHYDROGEIIASE

1

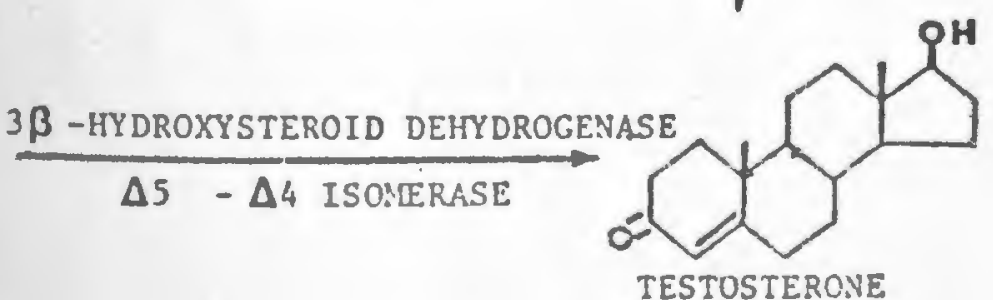

TESTOSTERONE 
Figure 2. Lineweaver-Burk replots of PREG:3BHSOR reactions in rabbit and guinea pig testis microsomes. Incubations run in presence of .1M Tris, $\mathrm{pH} 7.4,5 \mathrm{mM} \mathrm{MgCl} 2$ and $500 \mu \mathrm{M}$ NAD at $37^{\circ} \mathrm{C}$. Protein-65 $\mathrm{\mu g}$ (guinea pig), $185 \mu \mathrm{g}$ (rabbit). $\mathrm{k}_{0.5}=7 \mu \mathrm{m}$ (rabbit), $2.5 \mu \mathrm{M}$ (guinea pig). $\mathrm{v} \cdot .5 \mathrm{~nm} / \mathrm{min} / \mathrm{mg}$ (rabbit), $.77 \mathrm{~nm} / \mathrm{min} / \mathrm{mg}$ (g) 
Figure 3. Iineweaver-Burk replots of $17 \alpha \mathrm{PREG}: 3 \mathrm{BHSOR}$ reactions in rabbit and guinea pig testis microsomes. Incubations run in presence of .IM Tris, $\mathrm{pH} 7.4,5 \mathrm{mM} \mathrm{MgCl}_{2}$ and $500 \mu \mathrm{M}$ NAD at $37^{\circ} \mathrm{C}$. Protein-175 $\mathrm{kg}$ (rabbit), $161 \mathrm{\mu g}$ (guinea pig). $k_{0.5}=4 \mu M$ (rabbit), $6 \mu M$ (guinea pig). $\mathrm{v}_{\max }=.79 \mathrm{~nm} / \mathrm{min} / \mathrm{mg}$ (rabbit), .70 nm $/ \mathrm{min} / \mathrm{mg}$ (guinea pig). 


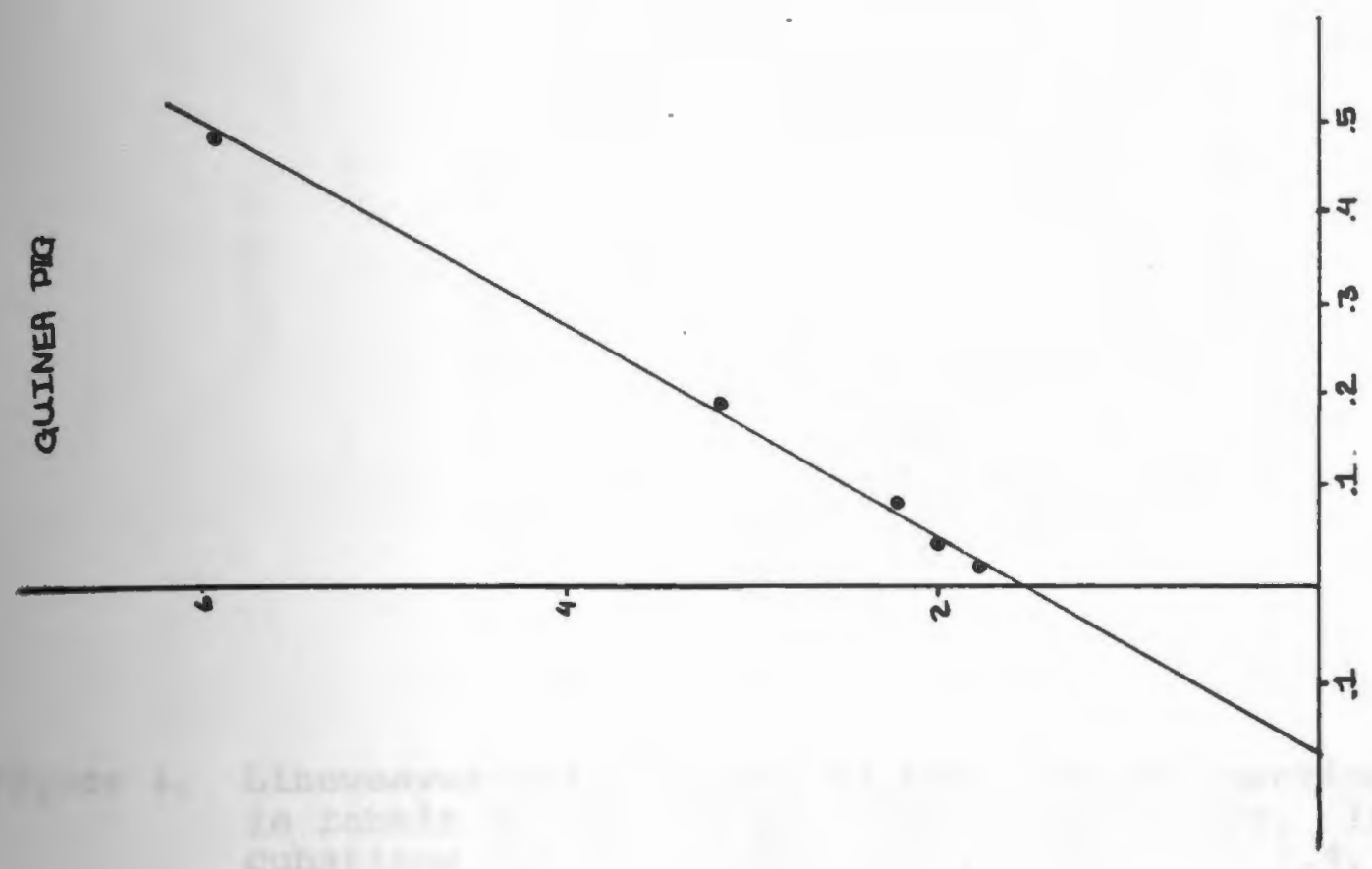

5
呆
d
$a$
$\mathbb{a}$

(6u/um/um) Dodd-21/F 
Figure 4, Lineweayer-Burk replots of DHEA:3BHSOR reactions in rabbit and guinea pig testis microsomes, Incubations run in presence of , IM Tris, pH 7,4, $5 \mathrm{mM} \mathrm{MgCl}_{2}$ and $500 \mu \mathrm{M}$ NAD at $37^{\circ} \mathrm{C}$, Protein-336 $\mathrm{gg}$ (rabbit), $197 \mathrm{\mu g}$ (guinea pigl $\mathrm{k}_{0} 5^{=2.0 \mu \mathrm{M}}$ (rabbit), $4.0 \mu \mathrm{M}$ (guinea pig). $\mathrm{V}_{\max }=\mathrm{k}_{0,5}=2.0 \mu \mathrm{M}$ (rabbit), $4.0 \mu \mathrm{M}$ (guine $\mathrm{pig}$ ). $\mathrm{V}_{\max }=.1 \mathrm{~nm} / \mathrm{min} / \mathrm{mg}$ (rabbit), $.43 \mathrm{~nm} / \mathrm{min} / \mathrm{mg}$ (guinea $\mathrm{p} 1 \mathrm{~g}$ ). 

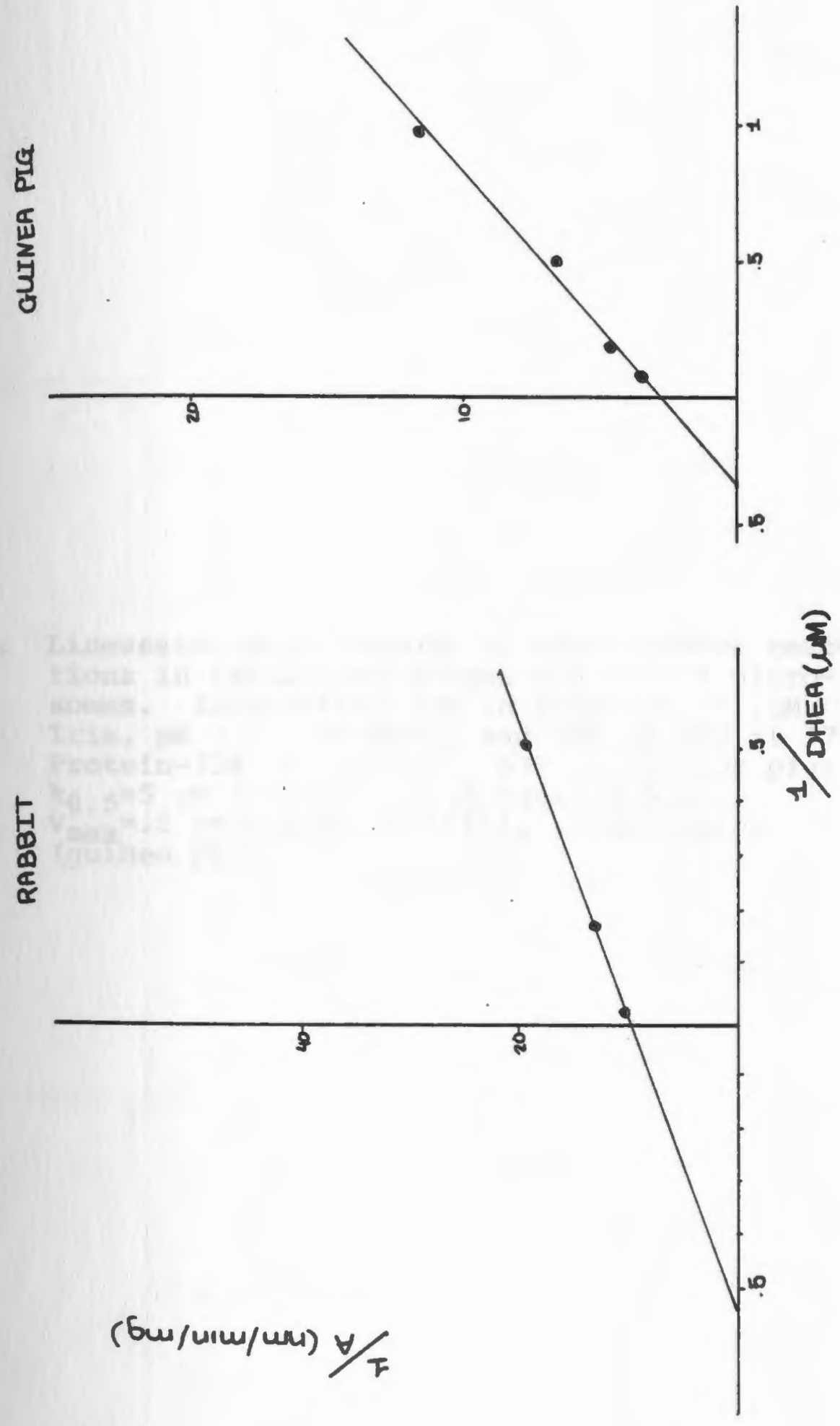
Figure 5. Lineweaver-Burk replots of ADIOL:3BHSOR reactions in rabbit and guinea pig testis microsomes. Incubations run in presence of .IM Tris, $\mathrm{pH} 7.4,5 \mathrm{mM} \mathrm{MgCl} 2$ and $500 \mu \mathrm{M} \mathrm{NAD}$ at $37^{\circ} \mathrm{C}$. Protein-336 $\mathrm{\mu g}$ (rabbit), $537 \mu \mathrm{g}$ (guinea pig). $\mathrm{k}_{0.5}=5 \mu \mathrm{M}$ (rabbit), $5 \mu \mathrm{M}$ (guinea pig).

$v_{\max }=.2 \mathrm{~nm} / \mathrm{min} / \mathrm{mg}$ (rabbit), .35nm/min $/ \mathrm{mg}$ (guinea pig). 


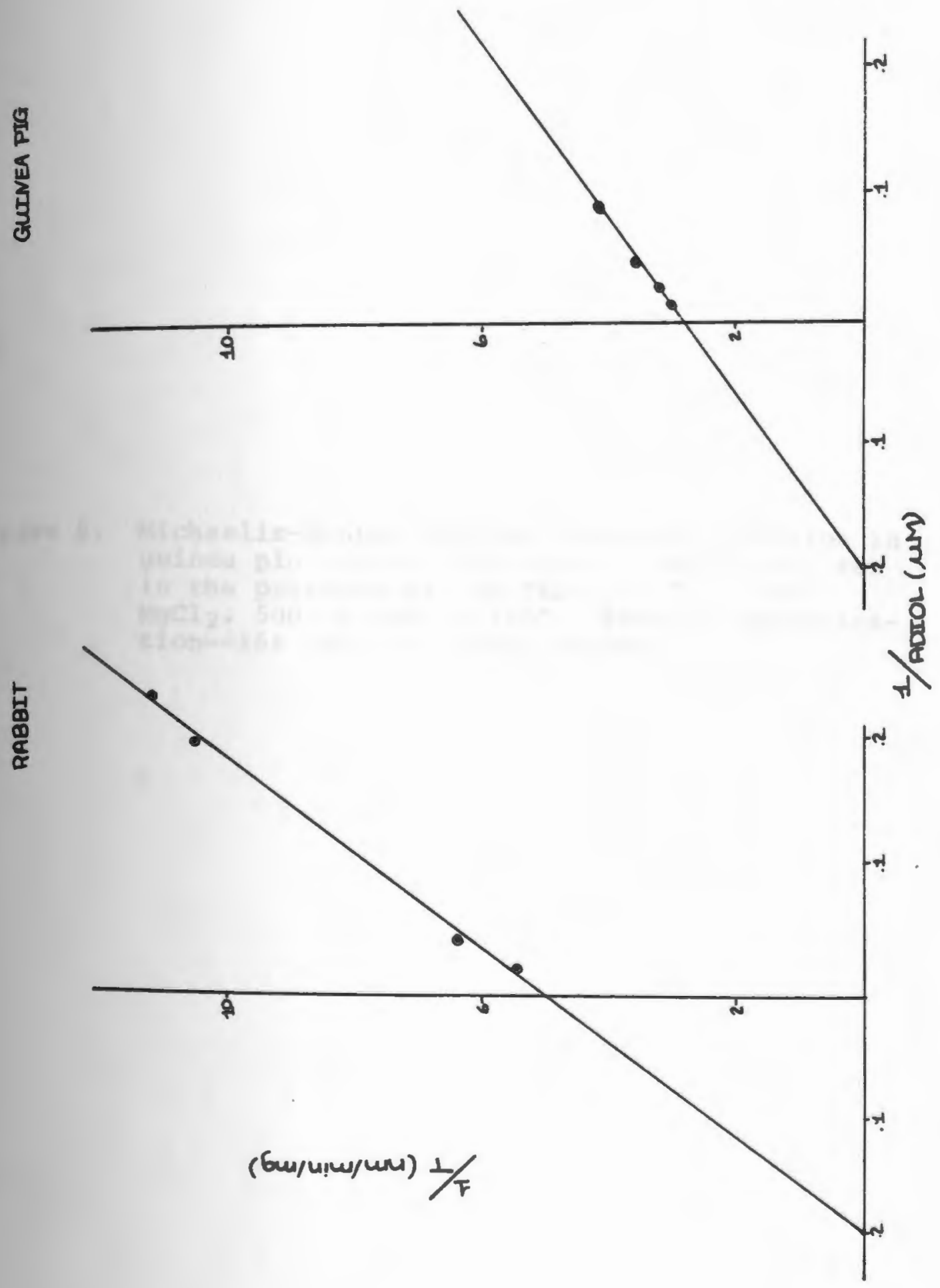


Figure 6. Michaelis-Menton plot of ADIOL $\rightarrow T$ reaction in guinea pig testis microsomes. Incubation run in the presence of .1M Tris, $\mathrm{pH} 7.4,5 \mathrm{mM}$, $\mathrm{MgCl}_{2}, 500 \mu \mathrm{M} \mathrm{NAD}$ at $37^{\circ} \mathrm{C}$. Protein concentration--16l $\mu \mathrm{g} / .1 \mathrm{ml}$ final volume. 


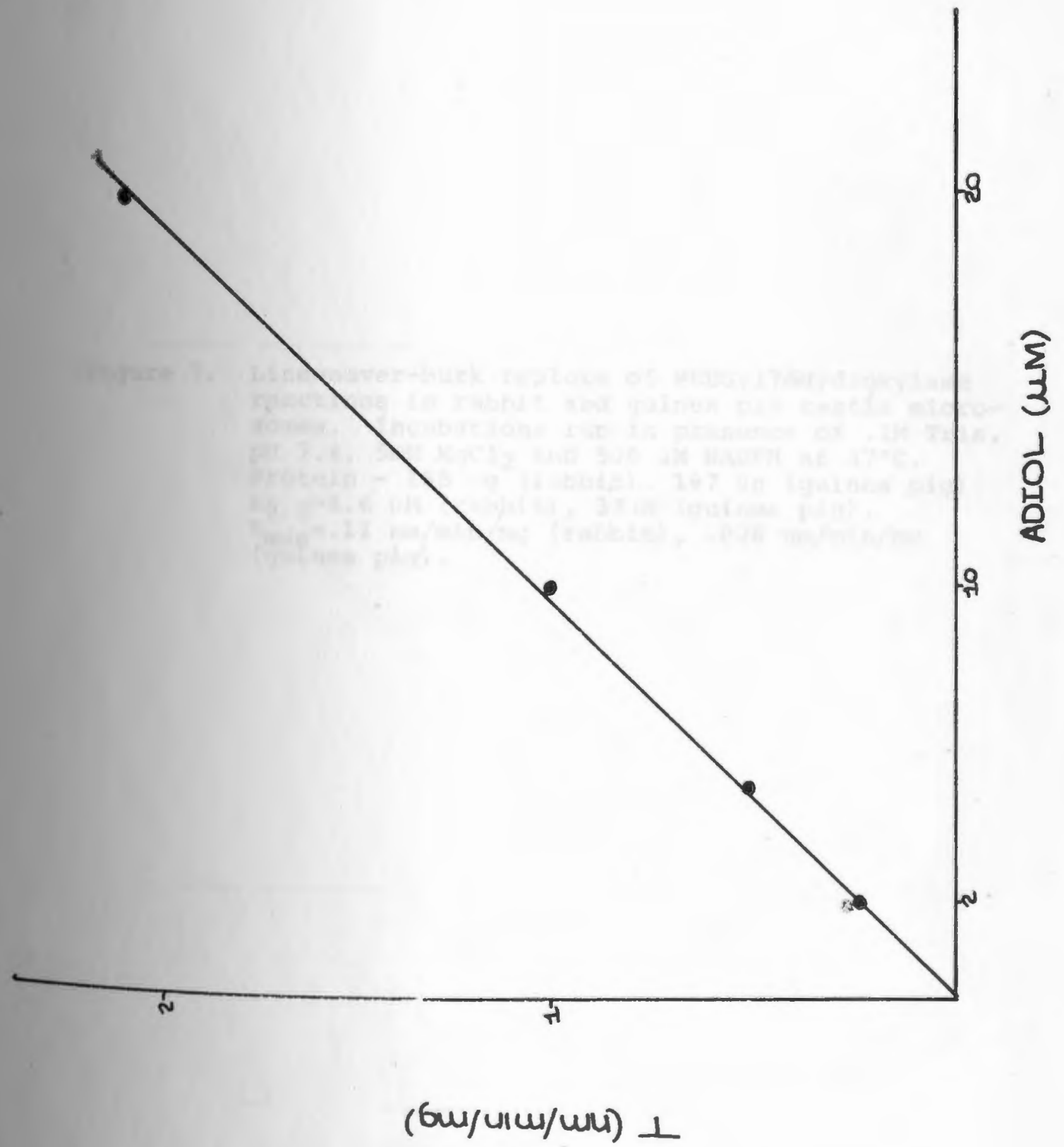


Figure 7. Lineweaver-Burk replots of PREG:17fHydroxylase reactions in rabbit and guinea pig testis microsomes. Incubations run in presence of .1M Tris, $\mathrm{pH} 7.4,5 \mathrm{mM} \mathrm{MgCl}_{2}$ and $500 \mu \mathrm{M} \mathrm{NADPH}$ at $37^{\circ} \mathrm{C}$. Protein - $185 \mu \mathrm{g}$ (rabbit), $197 \mu \mathrm{g}$ (guinea pig)

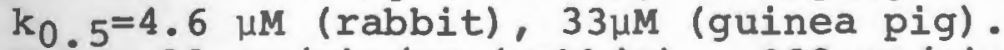
$\mathrm{V}_{\max }=.11 \mathrm{~nm} / \mathrm{min} / \mathrm{mg}$ (rabbit), .028 nm/min/mg (guinea pig). 
岁

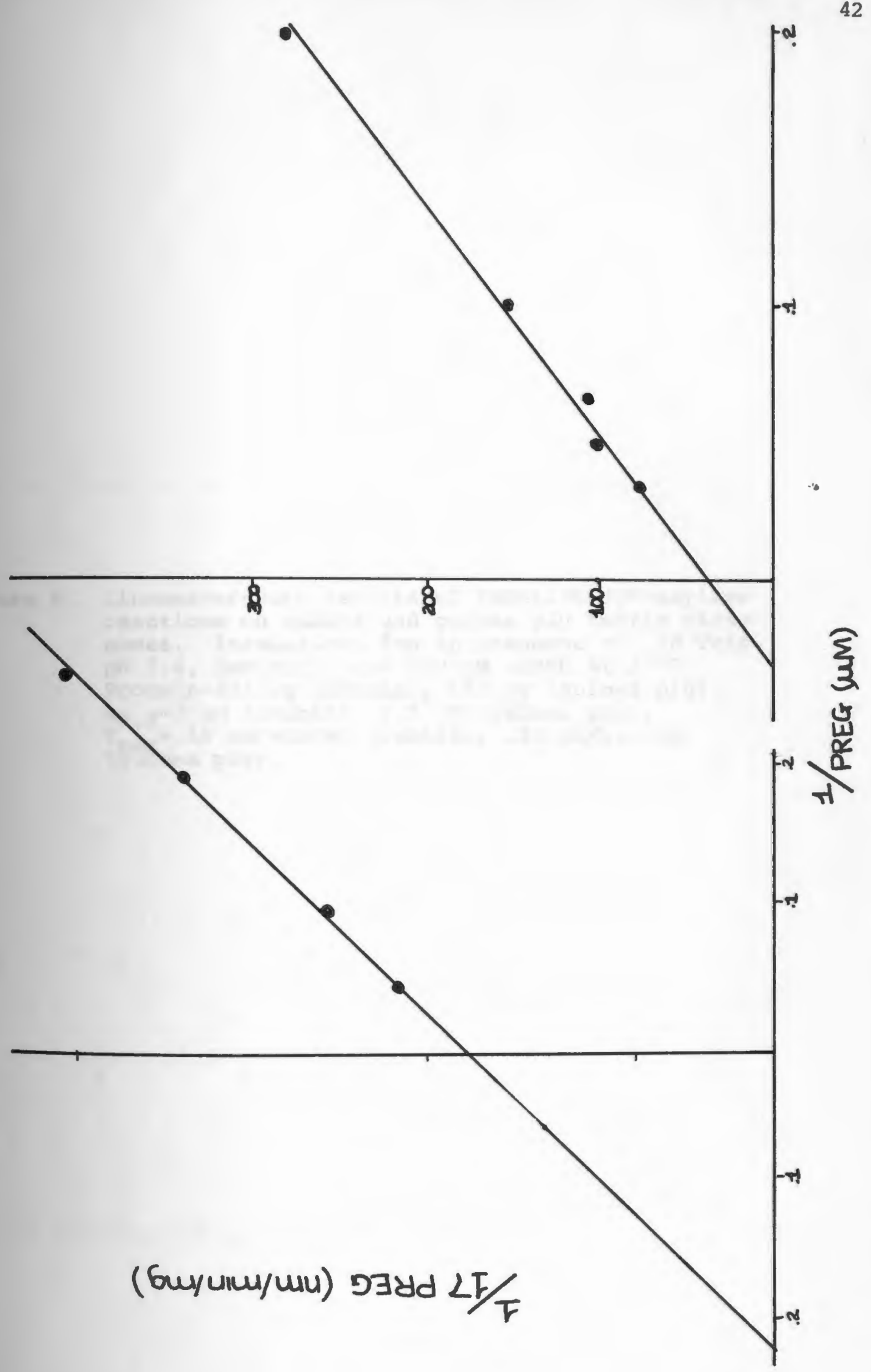


Figure 8. Lineweaver-Burk replots of PROG:17c-Hydroxylase reactions on rabbit and guinea pig testis microsomes. Incubations run in presence of .IM Tris, $\mathrm{pH} 7.4,5 \mathrm{mM} \mathrm{MgCl}_{2}$ and $500 \mu \mathrm{M} \mathrm{NADPH}$ at $37^{\circ} \mathrm{C}$. Protein-231 $\mu \mathrm{g}$ (rabbit), $182 \mu \mathrm{g}$ (guinea pig). $\mathrm{k}_{0.5^{2}}=2 \mu \mathrm{M}$ (rabbit), $1.5 \mu \mathrm{M}$ (guinea pig). $\mathrm{V}_{\max }=.16 \mathrm{~nm} / \mathrm{min} / \mathrm{mg}$ (rabbit), $.20 \mathrm{~nm} / \mathrm{min} / \mathrm{mg}$ (guinea pig). 


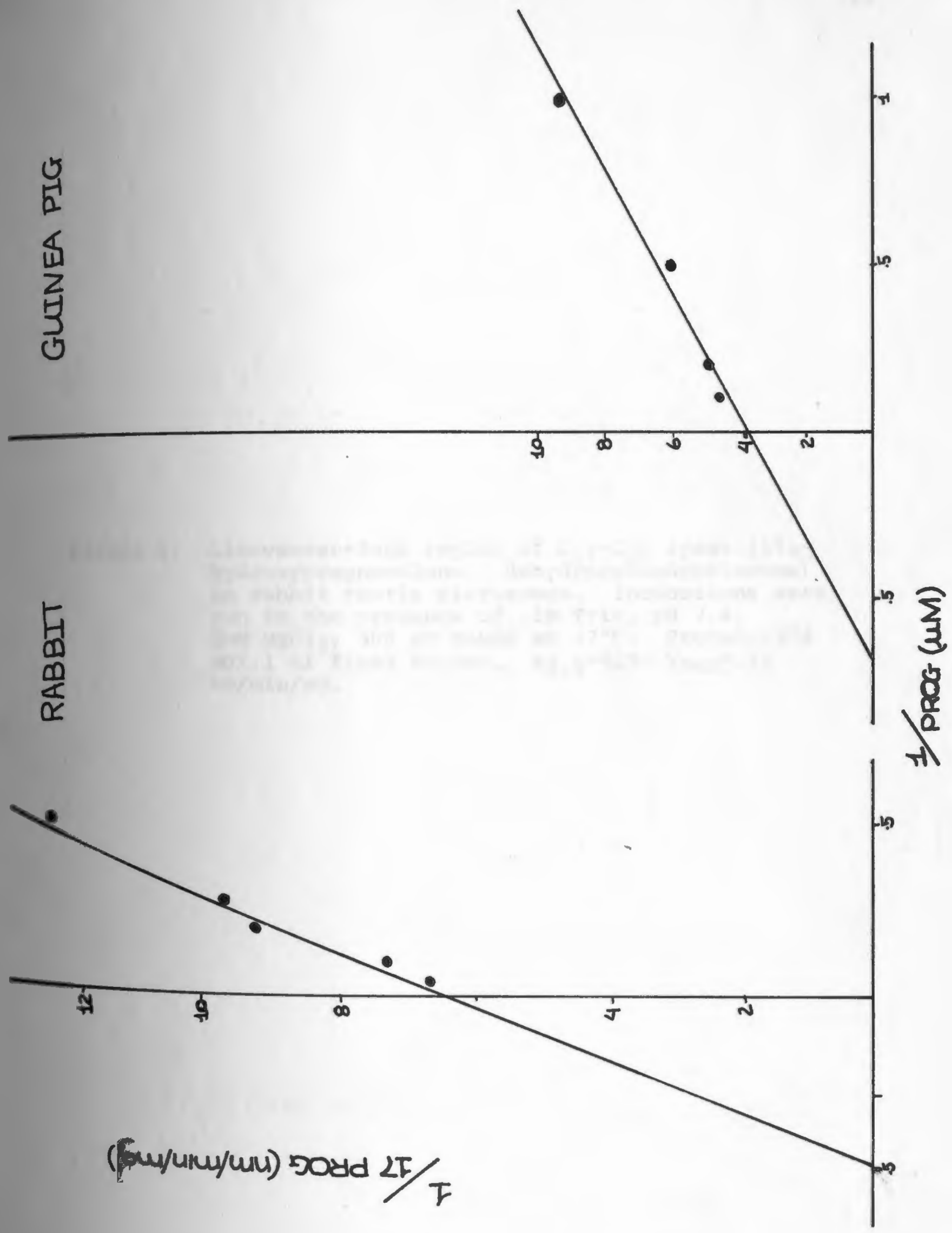


Figure 9. Iineweaver-Burk replot of $C_{17}-C_{20}$ Iyase: (17 $\alpha-$ hydroxypregnenolone dehydroepiandrosferone) in rabbit testis microsomes. Incubations were run in the presence of .IM Tris, $\mathrm{pH} \mathrm{7.4,}$ $5 \mathrm{mM} \mathrm{MgCl}_{2}, 500 \mu \mathrm{M}$ NADPH at $37^{\circ} \mathrm{C}$. Protein-374 $\mu \mathrm{g} / .1 \mathrm{ml}$ final volume. $\mathrm{k}_{0.5}=4 \mu \mathrm{M}, v_{\max }=.12$ $\mathrm{nm} / \mathrm{min} / \mathrm{mg}$. 


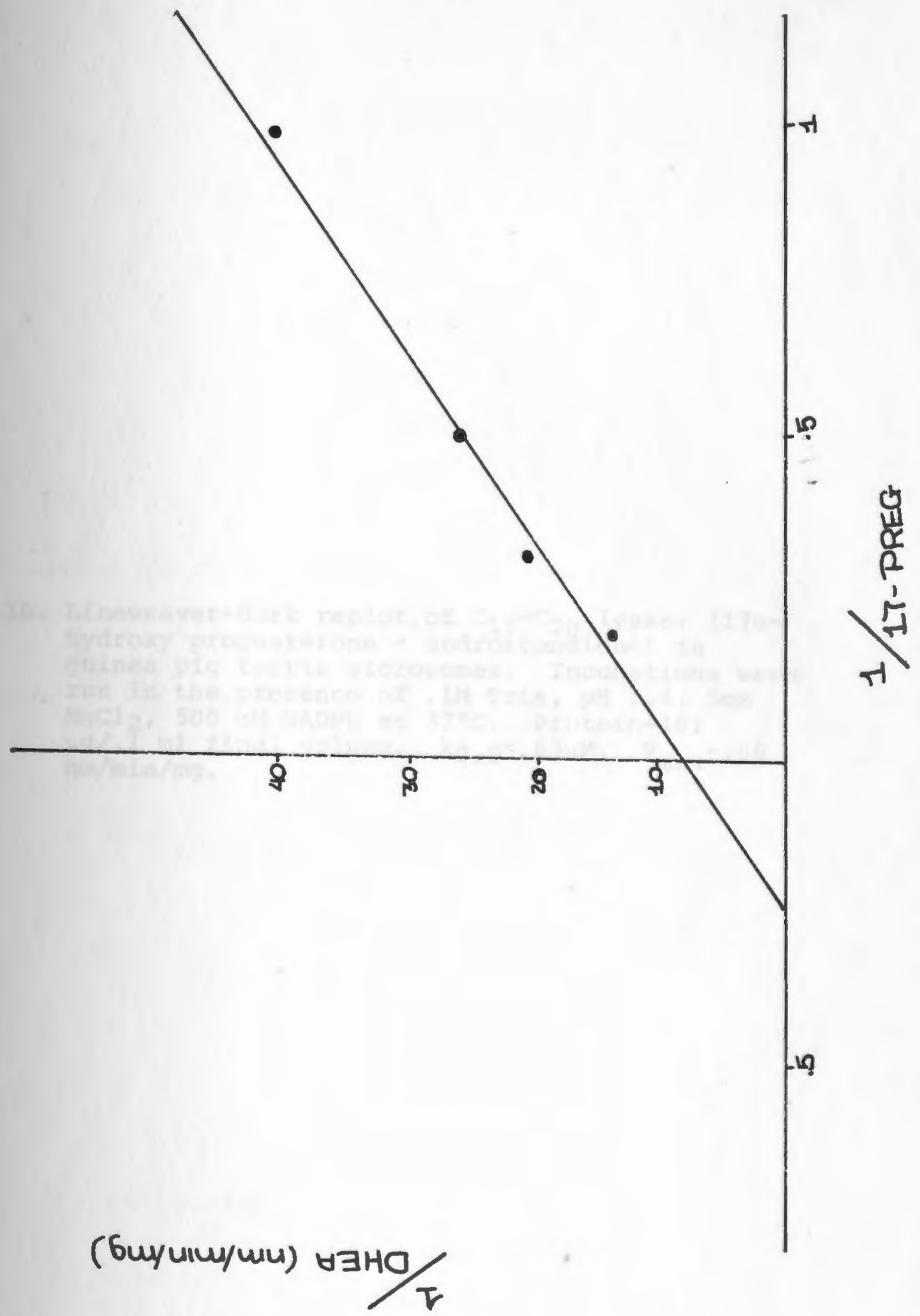




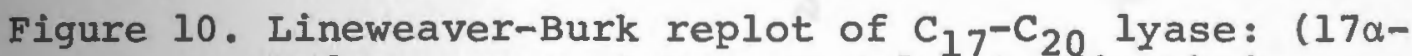
hydroxy progesterone - androstendione) in guinea pig testis microsomes. Incubations were run in the presence of .1M Tris, $\mathrm{pH} 7.4,5 \mathrm{mM}$ $\mathrm{MgCl}_{2}, 500 \mu \mathrm{M}$ NADPH at $37^{\circ} \mathrm{C}$. Protein-101 $\mu \mathrm{g} / . \mathrm{Iml}$ final volume. $\mathrm{k}_{0.5}=.63 \mu \mathrm{M}$. $\mathrm{v}_{\max }-.06$ $\mathrm{nm} / \mathrm{min} / \mathrm{mg}$. 


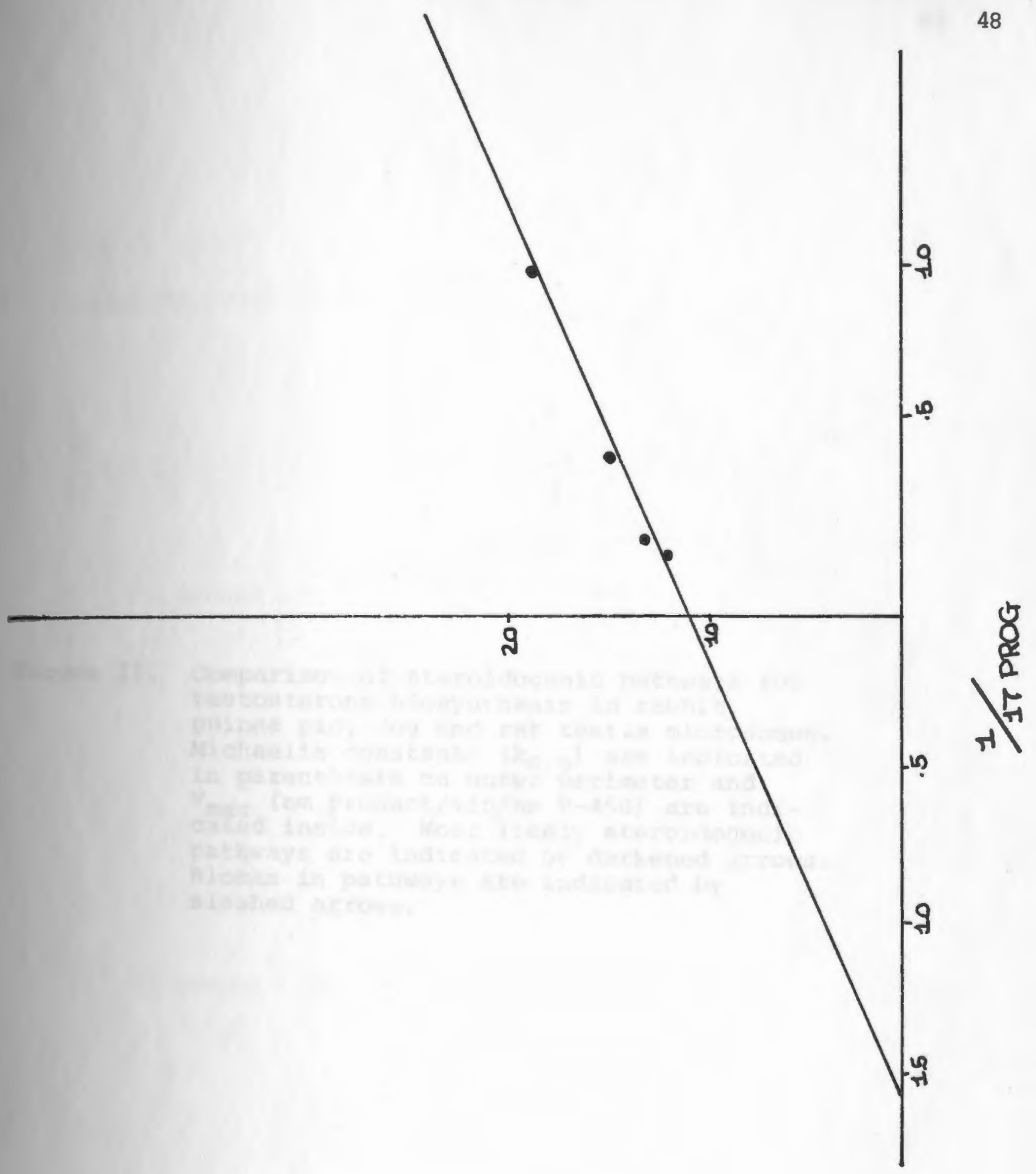

(6m/ uim/ums) $\forall / T$ 
Figure 11. Comparison of steroidogenic pathways for testosterone biosynthesis in rabbit, guinea pig, dog and rat testis microsomes. Michaelis constants $\left(\mathrm{k}_{0.5}\right)$ are indicated in parenthesis on outer perimeter and $\mathrm{V}_{\max }(\mathrm{nm}$ product/min/nm $\mathrm{P}-450$ ) are indicated inside. Most likely steroidogenic pathways are indicated by darkened arrows. Blocks in pathways are indicated by slashed arrows. 
SUMMARY OF KINETIC DATA IN FOUR SPECIES

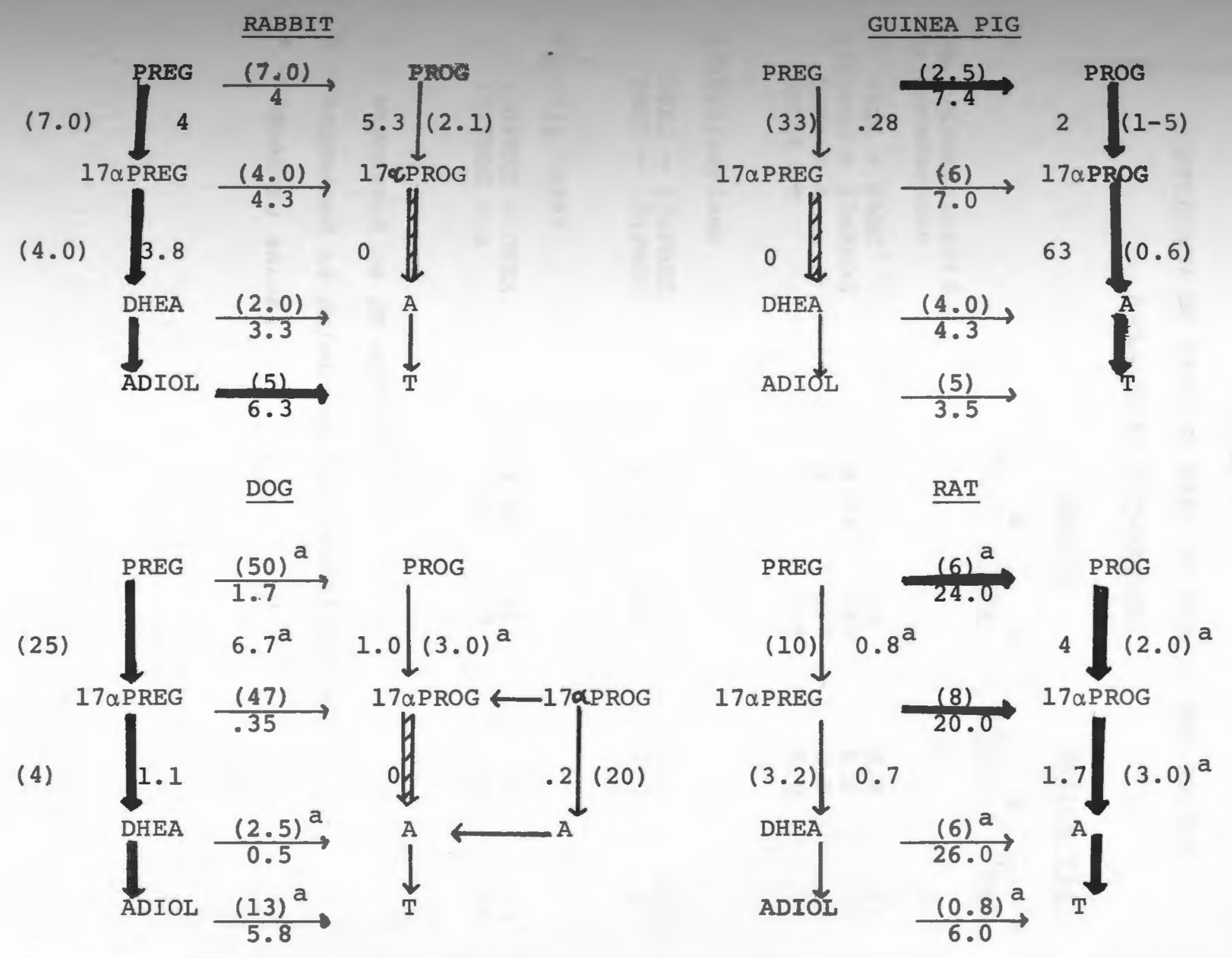

$\bar{a}$ Data courtesy of Joanne V. Hologittas, Dept. of Biochemistry and Biophysics, University of Rhode Island. 


\section{TABLE I}

\section{COMPARISON OF KINETIC DATA IN RABBIT AND GUINEA \\ PIG TESTIS MICROSOMES}

Rabbit

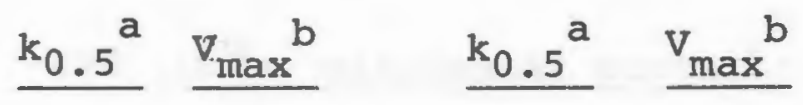

3B-Hydroxys teroid Cxidoreductase



$\begin{array}{ll}7.0 & .12 \\ 4.0 * & .79 * \\ 2.0 & .099 \\ 5.0 & .189\end{array}$

2.5

.77

6.0

.70

4.0

5.0

.38

.35

\section{7atlydroxylase}

PREG $\rightarrow 17 \alpha$ PREG
PROG $\rightarrow 17 \alpha$ PROG

$\mathrm{C}_{17}-\mathrm{C}_{20}$ Lyase

$17 \alpha$ PREG $\rightarrow$ DHEA

$17 \alpha \mathrm{PROG} \rightarrow \mathrm{A}$
$7.0 \quad .12$

$2.1 \quad .16$

$\begin{array}{rr}4.0 & .11 \\ 0 & 0\end{array}$

$\begin{array}{cc}0 & 0 \\ .63 & .06\end{array}$

\footnotetext{
a - expressed as $\mu \mathrm{M}$ substrate

b - expressed as $\mathrm{nm} / \mathrm{min} / \mathrm{mg}$ microsomal protein

* - immature animal
} 
TABLE II

CYTOCHROME P-450 LEVELS OF TESTIS

MICROSOMES IN FOUR SPECIES

\section{$\underline{\mathrm{P}-450(\mathrm{~nm} / \mathrm{mg} \text { microsomal protein) }}$}

$\begin{array}{lc}\text { RABBIT (mature) } & .03 \\ \text { RABBIT (immature) } & .185 \\ \text { GUINEA PIG } & .10 \\ \text { DOG }^{\mathrm{a}} & .12^{\mathrm{b}} \\ \mathrm{RAT}^{\mathrm{a}} & .05\end{array}$
a - Data - courtesy of Joanne v. Hologittas, Department of Biochemistry \& Biophysics, University of Rhode Island, Kingston.
b - Average value, mixed species, long-legged dogs.


TABLE III

TESTIS MICROSOMAL

3B-HYDROXYSTEROID OXIDOREDUCTASE ACTIVITY*

IN FOUR SPECIES: $k_{0.5}$ and $v_{\max }$

$\begin{array}{llll}\text { RABBIT } & \text { GUINEA PIG }\end{array}$

$\underline{k_{0.5}{ }^{c} v_{\max }{ }^{d} k_{0.5}{ }^{c} v_{\max }{ }^{d} k_{0.5}{ }^{c} v_{\max }{ }^{d} k_{0.5}{ }^{c} v_{\max }{ }^{d}}$

Substrate

PREG $\quad 7.0 \quad 4.0 \quad 2.5 \quad 7.7 \quad 50^{\mathrm{b}} \quad 1.7^{\mathrm{b}} \quad 6.0^{\mathrm{b}} \quad 24.0^{\mathrm{b}}$

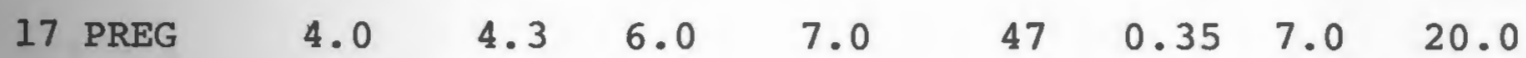

DHEA $\quad 2.0 \quad 3.3 \quad 4.0 \quad 4.3 \quad 2.5^{\mathrm{b}} 0.50^{\mathrm{b}} 6.0^{\mathrm{b}} \quad 26.0^{\mathrm{b}}$

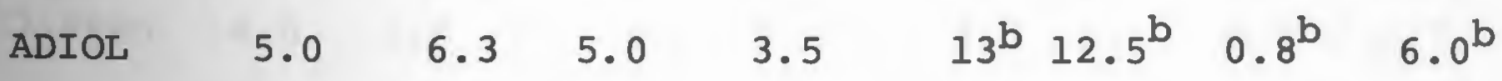

a - enzyme assays were conducted at $\mathrm{pH} 7.4,37^{\circ} \mathrm{C}$ in the presence of .lM Tris, $5 \mathrm{mM} \mathrm{MgCl} 2,500 \mu \mathrm{M} \mathrm{NAD}, 1 \%$ propylene glycol.

b - data courtesy of Joanne V. Hoboggitas, Dept. of Biochemistry and Biophysics, University of Rhode Island, Kingston.

$c-k_{0.5}$ - expressed as $\mu \mathrm{M}$ concentration substrate.

d $-\mathrm{V}_{\max }$ - expressed as $\mathrm{nm}$ product min/nm $\mathrm{P}-450$. 


\section{TABLE IV}

TESTIS MICROSOMAL 17 HYDROXYLASE AND LYASE ACTIVITY ${ }^{a}$ IN FOUR SPECIES : $k_{0.5}{ }^{b}$ and $v_{\max }{ }^{c}$

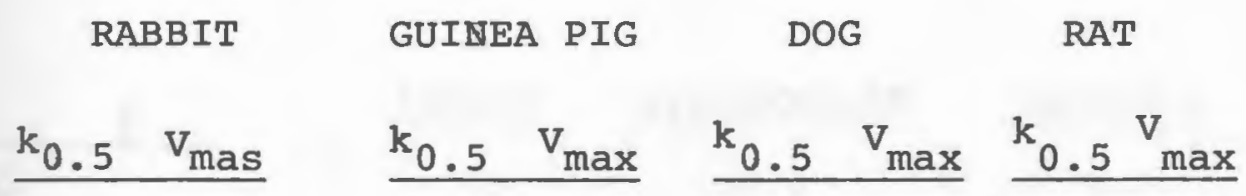

17 Hydroxyl-

ase

$\begin{array}{lrrrrrrrr}\text { PREG } & 7.0 & 4.0 & 33.0 & 0.28 & 25.0 & 6.7 & 10.0 & 0.8 \\ \text { PROG } & 2.1 & 5.3 & 1.5 & 2.0 & 3.0^{\mathrm{d}} & 1.6^{\mathrm{d}} & 2.0^{\mathrm{d}} & 4.0^{\mathrm{d}}\end{array}$

$\mathrm{C}_{17}-\mathrm{C}_{20}$

Lyase
$17 \alpha$ PREG
$4.0 \quad 3.8$
$0 \quad 0$
4.01 .1
3.20 .7
$17 \alpha$ PROG
0
0
$0.6 \quad 0.63$
00
$3.0^{\mathrm{d}} \quad 1.7^{\mathrm{d}}$

a - enzyme assays were conducted at $\mathrm{pH} 7.4,37^{\circ} \mathrm{C}$ in the presence of .IM Tris, $5 \mathrm{mM} \mathrm{MgCl}_{2}, 500 \mu \mathrm{M} \mathrm{NAD}, 18$ propylene glycol.

b - $k_{0.5}$ - expressed as $\mu_{M}$ concentration of substrate.

c - $\mathrm{V}_{\text {max }}$ - expressed as $\mathrm{nm}$ product/min/nm P-450.

d - data courtesy of Joanne v. Hologgitas, Dept. of Biochemistry and Biophysics, University of Rhode Island, Kingston. 


\section{TABLE V}

MICHAELIS CONSTANTS $\left(k_{0.5}\right)^{a}$ FOR PREGNENOLONE

IN 3BHSOR AND HYDROXYLASE REACTIONS

3BHSOR HYDROXYLASE $\underline{3 B H S O R / H}$

GUINEA PIG

2. 5

25.0

0.1

RAT

6.0

10.0

0.6

RABBIT

7.0

$7 \cdot 0$

1.0

DOG

50.0

25.0

2. 0

a $-k_{0.5}$ expressed in $\mu M$ PREG. 
TABLE VI

RELATIONSHIP OF 17 HYDROXYLASE ${ }^{a, b}$ ACTIVITIES

IN FOUR SPECIES

$$
\begin{aligned}
& \frac{k_{0.5}^{a}}{\text { PROG PREG }} \quad \frac{v_{\max }{ }^{b}}{\text { PROG PREG }} \quad \frac{k_{0.5 \text { Ratio }}}{\text { PROG/PREG }} \frac{v_{\max R a t i o}}{\text { PROG/PREG }} \\
& \text { Guinea Pig } \\
& \begin{array}{llll}
1.5 & 25.0 & 2.0 & 0.28
\end{array} \\
& .06 \\
& 7 \\
& \text { Rat } \\
& 2.0 \quad 10.0 \\
& \begin{array}{lll}
4.0 & 0.8
\end{array} \\
& .20 \\
& 5 \\
& \text { Rabbit } \\
& 2.1 \quad 7.0 \\
& 5.34 .0 \\
& .30 \\
& 1.25 \\
& \text { Dog } \\
& 3.025 .0 \\
& 1.0 \quad 6.7 \\
& .12 \\
& 0,15
\end{aligned}
$$
a $-\mathrm{k}_{0.5}$, expressed as $\mu \mathrm{M}$ substrate.
b - $V_{\text {max }^{\prime}}$ expressed as $\mu \mathrm{m}$ product/min/nm P-450. 
TABLE VII

RATIO OF LYASE/HYDROXYLASE ACTIVITY ${ }^{a}$

FOR PREGNENOLONE AND PROGESTERONE

IN FOUR SPECIES

\begin{tabular}{lcr} 
& \multicolumn{2}{c}{ LYASE/HYDROXYLASE } \\
\cline { 2 - 3 } RAT & $\frac{\text { PROG }}{\underline{\text { PREG }}}$ \\
GUINEA PIG & $1: 2.3$ & $1: 1.1$ \\
DOG & $1: 3.2$ & 0 \\
RABBIT & 0 & $1: 6$ \\
& 0 & $1: 1.1$
\end{tabular}

a - on the basis of $V_{\text {max }}$, expressed as $\mathrm{nm}$ prod/min/nm $\mathrm{P}-450$. 
II. THE EFFECT OF ASCORBIC ACID ON 3-B HYDROXYSTEROID: NAD-OXIDOREDUCTASE ACTIVITY IN THE TESTIS 
INTRODUCTION

Efforts to elucidate the role of ascorbic acid in steroidogenesis have been both controversial and contradictory. Ascorbic acid has been shown to exert an inhibitory effect on steroid hydroxylations in the mitochondria $(1,2,3)$ and microsomes $(4,5,6,7)$ of steroid producing tissues, suggestive of a "braking" role in the control of steroid synthesis. Slight stimulation of adrenal steroid synthesis in guinea pigs during the early stages of scurvy (8) and decreased cholesterol levels in the testes of scorbutic guinea pigs (9) suggest release of inhibition on the cholesterol side chain cleavage enzymes as ascorbic acid levels are lowered.

Other studies have demonstrated a stimulatory effect of ascorbic acid on the conversion of pregnenolone to progesterone (10). 3B-hydroxysteroid:NAD-oxidoreductase (EC 1.1.1.145) activity was found to be inhibited in vitamin A deficient rats (11). The vitamin A deficient rat is unable to synthesize ascorbic acid and addition of ascorbic acid to the diet promotes restoration of 3BHSOR activity.

The mechanism by which ascorbic acid stimulates 3BHSOR activity is uncertain. It has been proposed that the vitamin may release NADH inhibition through a monodehydroascorbatedependent oxidation of the reduced pyridine nucleotide (12, 13,141. Two distinct enzymes have been reported to be involved in the transport of electrons from NADH to monodehydro- 
ascorbate (15). Ninety percent of the electron transport from NADH to monodehydroascorbate in microsomes goes via NADHnodehydroascorbate oxidoreductase, (EC 1.6.5.4), and the remaining $10 \%$ through cytochrome $b_{5}$ via ascorbate:ferricytochrome $\mathrm{b}_{5}$ oxidoreductase (EC 1.10.2.1). The physiological function of these proteins is unclear. It is not known whether they operate exclusively as a conservation mechanism for ascorbic acid by reducing free radical formation, or, function to generate oxidized cofactor for steroid synthesis.

This mechanism cannot totally explain the stimulation of 3BHSOR by ascorbic acid. Staudinger (13) demonstrated that the oxidation of NADH was strictly specific for reduced ascorbic acid. However, dehydroascorbic acid has been shown to stimulate 3BHSOR activity in toad testes (16). Depressed NAD/NADH ratios were reported in the tissues of ascorbic acid deficient guinea pigs although no inhibition of the ascorbate linked oxidase was apparent (17).

This study was undertaken to examine the effect of ascorbic acid on 3BHSOR in the testis using the guinea pig with latent hypovitaminosis $\mathrm{C}$ as a model. Microsomal 3BHSOR activity was examined in deficient and control animals with four known substrates for the enzyme using a sensitive microassay. 
METHODS AND MATERIALS

perimental Animals

Twelve, all male, Hartley guinea pigs were obtained from Charles River Laboratories, Wilmington, Massachusetts. Animals were purchased at 10 days of age (150-200 grams) and were maintained on rabbit chow (Agway, Kingston, Rhode Island) and supplemented with $10 \mathrm{mg}$-ascorbic acid/day, administered by oral intubation. Feed and water were supplied ad libitum and animals were raised for 4 weeks prior to commencement of feeding experiment.

\section{Teeding Experiment}

Animals were divided into two groups at 35 days of age. Mean weights were $360 \mathrm{gm}$ (Group I) and $376 \mathrm{gm}$ (Group II). Group I served as the control and received rabbit chow plus $10 \mathrm{mg} \ell$-ascorbic acid (ICN Biochemicals, Plainview, N.Y.) in $.5 \mathrm{ml}$ distilled water, daily, by oral intubation. L-ascorbic acid solutions were prepared immediately prior to use. Group II was maintained on rabbit chow and received $.5 \mathrm{ml}$ distilled water by oral intubation. Vitamin $C$ content of the diet was determined to be $43.75 \mathrm{~g}$ per gram of diet. The diet supplied an ascorbic acid intake of approximately $1.3 \mathrm{mg} /$ day for the hypovitaminosis $C$ group, (average intake=30 gm/day), and diet plus oral supplement supplied $11.3 \mathrm{mg} /$ day ascorbic acid in the control. Animals were housed individually and feed and water were supplied ad libitum. Animals were weighed 
weekly to monitor onset of Vitamin C deficiency. Control animals were maintained for 9 weeks and the hypervitaminosis C group was maintained until animals began to lose weight (9-13 weeks).

Animals were sacrificed by cervical dislocation. Plasma samples were immediately drawn by cardiac-puncture into heparinized syringes and placed on ice prior to centrifugation at $4^{\circ} \mathrm{C}$. Testes were quickly removed and placed on ice in $.25 \mathrm{M}$ sucrose. Testes were homogenized in .25M sucrose (10\% $w / v)$ as described in Manuscript I. Reduced ascorbic acid in plasma and testes homogenates were determined by the micromethod of Zannoni et al. (18).

\section{pration of Testis Microsomes}

This procedure was conducted as previously described in Manuscript I.

\section{Byme Incubations}

Assay of 3BHSOR activity in testes microsomes was performed as described in Manuscript I with the exception that $\ell$-ascorbic acid and $\ell$-dehydroascorbic acid were added at concentrations of $2.0 \mathrm{mM}$ where indicated. Microsomes from control and hypovitaminosis C animals were pooled for the enzyme incubations.

\section{Vitamin C Content of Diet}

Reduced ascorbic acid content of the diet was determined by the method of Zannoni et al. (19), with the following 
modification; ascorbic acid was extracted from 1 gram of diet into $5 \mathrm{ml}$ of 58 trichloroacetic acid. The extract was filtered and rinsed several times with 58 TCA solution and adjusted to a final volume of $10 \mathrm{ml}$. An internal standard was used to check for completeness of extraction. Ascorbic acid content was verified by using the AOAC 2,6,dichloroindophenol method (19). 
RESULTS

\section{PLASMA AND MICROSOMAL ASCORBIC ACID VALUES}

The results of ascorbic acid analysis of plasma and testes microsomes from experimental and control guinea pigs are summarized in TABLE I. The plasma ascorbic acid levels were significantly ( $p \ll .05$ ) lowered in the hypovitaminosis $C$ group after 9-13 weeks on the diet supplying $1.3 \mathrm{mg}$ ascorbic acid/ day. Testis microsomal ascorbate levels were also significantly lower in the hypovitaminosis $\mathrm{C}$ animals.

BODY AND TESTES WEIGHTS

Mean body weight of the hypovitaminosis C group was significantly lower $(p<.05)$ after nine weeks on the experimental diet (TABLE II). The wide range in body weights in this group represents the animals that had not begun to lose weight at 9 weeks. No significant difference was seen between mean testes weights. Surprisingly, the microsomal protein was found to be increased in the hypovitaminous $c$ group.

\section{BHSOR ACTIVITY IN GUINEA PIG TESTIS MICROSOMES}

Michaelis constants and $v_{\max }$ values for the $3 \mathrm{BHSOR}$ reaction using PREG, 17 $\alpha$ PREG, DHEA and ADIOL as substrate were estimated by the graphic method of Lineweaver-Burk (20) and are summarized in TABLE III. The $k_{0.5}$ for NAD in the 3BHSOR reaction was determined to be $35 \mu \mathrm{M}$ (Figure 1) and all enzyme 
Incubations were carried out at greater than saturation levels of the coenzyme. The $k_{0.5}$ for PREG in the $3 B H S O R$ reaction was found to be similar in both control and hypovitaminosis $\mathrm{C}$ guinea pig testis microsomes (Figure 2), although the $\mathrm{V}_{\max }$ was inhibited 648 by the hypovitaminous $C$ pretreatment. The Michaelis constants of the $3 B$ HSOR reaction for $17 \alpha$ PREG, DHEA and ADIOL (Figures 3-5) were found to be slightly lower in the testis microsomes from the hypovitaminosis $\mathrm{C}$ animals but these differences are considered to be negligible. The most severe inhibition of the $V_{\max }$ by hypovitaminosis $c$ pretreatment was seen in the 17aPREG $\rightarrow$ 17CPROG reaction where inhibition at saturation reached $76 \%$. Lesser inhibition was seen in the DHEA $\rightarrow A$ and ADIOL $\rightarrow T$ reactions, $49 \circ$ and 37\%, respectively.

Since ascorbic acid levels in whole testes of the normal guinea pig were reported to be $36.5 \pm 1.1 \mathrm{mg} / 100 \mathrm{gm}$ (21), representing an ascorbic acid concentration of approximately $2 \mathrm{mM}$, ascorbic acid and dehydroascorbic acid were added back to in vitro incubations of the hypovitaminosis testis microsomes at this level. Results are summarized in TABLE IV. Both ascorbic acid and dehydroascorbic acid stimulated 3BHSOR activity at intermediate levels of substrate. No stimulation by ascorbic acid was seen at low substrate concentrations nor at very high substrate concentrations and at no time was activity restored to the level of the control animals. The stimulation of $3 B H S O R$ activity with ascorbate is at least partially protein dependent. The greatest effect was seen 
with high protein concentrations where product formation reached $165 \%$ and $155 \%$ of the reference value in the presence of ascorbic acid and dehydroascorbic acid at $5 \mu \mathrm{M}$ substrate. Similar stimulation of 3BHSOR activity is seen with high protein concentrations at the $10 \mu \mathrm{M}$ substrate level. The dependence of this stimulatory effect upon protein and substrate concentrations suggests that ascorbic acid may be acting to reverse product inhibition. The two products of the reaction, NADH and progesterone are known to be inhibitors of $3 B H S O R$ activity. Since NADH is a competitive inhibitor of NAD it is not likely to be inhibitory with low product appearance in the presence of 500 $\mathrm{M}$ NAD. Progesterone inhibition of the 3BHSOR is noncompetitive (22) with an estimated $k_{i}$ of $2.5 \mu \mathrm{M}$ (Figure 6) in guinea pig testes microsomes. It appeared possible that the ascorbic acid may be reversing product inhibition by progesterone. Microsomes were incubated in the presence of $2 \mu \mathrm{M}$ and $5 \mu \mathrm{M}$ progesterone, 2 to $20 \mu \mathrm{M}$ substrate, with and without the addition of $2 \mathrm{mM}$ ascorbate or dehydroascorbate. Neither ascorbic acid nor dehydroascorbic acid were able to reverse progesterone inhibition of 3BHSOR activity. 


\section{DISCUSSION AND CONCLUSIONS}

The increase in the amount of microsomal protein isolated from the testes of the hypovitaminosis C guinea pigs bears review. It is clear that this increase in protein is not the result of testicular hypertrophy since the testes weights were similar in both groups. The discussion of increased microsomal protein synthesis in the ascorbic acid deficient guinea pig is not within the scope of this study. Since only 30-40\% of the microsomes are isolated by the preparation procedure, the increase in microsomal protein may simply be due to an increased yield of microsomes. To answer this question a study would need to be conducted employing a microsomal marker in the whole testes homogenate to quantitate the amount of microsomes present in order to determine 8 yield. No decrease in the amount of cytochrome P-450 could be detected in the testis microsomes of the hypovitaminosis $C$ pretreated guinea pigs. The activity of PROG-17ahydroxylase was used as a marker for the $\mathrm{P}-450$ as this enzyme has been shown to exhibit a constant activity/nm P-450 in testis microsomes (23). $V_{\max }$ for the reaction in the control testis microsomes was previously determined to be $.24 \mathrm{~nm} / \mathrm{min} / \mathrm{mg}$ and was found to be $.19 \mathrm{~nm} / \mathrm{min} / \mathrm{mg}$ in deficient microsomes. As the amount of $\mathrm{P}-450$ in microsomal preparations is inversely related to the amount of protein isolated, this activity must be corrected for the $20 \%$ Increase in microsomal protein. On this basis, the activities 
of the $17 \alpha$-hydroxylase in the control and hypovitaminosis $C$ microsomes are identical. This data is in contrast to Degwitz et al. (24) who demonstrated a $30 \%$ decrease in liver tochrome P-450 synthesis following 28 day depletion of ascorbic acid. It is apparent that tissue differences may exist with respect to the protoheme synthesis for $\mathrm{P}-450$ and also probable that chronic hypovitaminosis $C$ may not affect cytochrome P-450 levels to the extent that is seen in the scorbutic animal.

3BHSOR activity was found to be inhibited in testis microsomes isolated from guinea pigs with hypovitaminosis $C$. This inhibition was present with all four substrates for the enzyme, although the 8 inhibition was greatest in the reactions having the highest rates of product formation. In vitro additions of ascorbic acid and dehydroascorbic acid were most effective in stimulating 3BHSOR activity with PREG as substrate under conditions where the reaction rate was maximal (i.e., saturating substrate and high protein concentrations). It appears that ascorbic acid may function in some manner which releases product inhibition on the enzyme. The reversal of NADH inhibition of 3BHSOR activity by ascorbic acid has been demonstrated in rat adrenal preparations (12), although the ascorbic acid concentration used was $40 \mathrm{mM}$ which is far greater than physiological levels in the testes, and the NADH concentration was $300 \mu \mathrm{M}$. The incubation procedure used in this study produces $\mathrm{NADH}$ at a maximum velocity of .77 $\mathrm{nm} / \mathrm{min} / \mathrm{ng}$ in controls and $.28 \mathrm{~nm} / \mathrm{min} / \mathrm{ng}$ in the deficient group. 
This would allow for an average NADH concentration from .7-1.0 $\mu M$ under the assay conditions employed. Since NADH is continually being oxidized in testes microsomes via cytochrome $b_{5}$, the average concentration is probably much lower than predicted. Inhibition of 3BHSOR activity in testes microsomes of hypovitaminous C guinea pigs and stimulation of enzyme activity with ascorbate and dehydroascorbate in the presence of 500 M NAD can not be explained on the basis of NADH oxidation alone. The monodehydroascorbate-NADH oxidoreductase demonstrated by staudinger (13) is strictly specific for reduced ascorbic acid. Therefore, the oxidase could not explain the stimulation of 3 BHSOR activity seen with dehydroascorbate in this study and in toad testes (16). NADH has been found to inhibit 3BHSOR noncompetitively with respect to pregnenolone in the $0-40 \%\left(\mathrm{NH}_{4}\right)_{2} \mathrm{SO}_{4}$ fraction of human testis preparations (22) but the $\mathrm{k}_{i}$ for $\mathrm{NADH}$ was estimated to be $150 \mathrm{M}$. Since this concentration could never be attained under the assay conditions of the present study, this model can not explain the release of inhibition on $3 B H S O R$ by ascorbic acid. The data suggest that ascorbic acid does not function in the reversal of product inhibition on 3BHSOR since NADH inhibition is unlikely and progesterone inhibition cannot be reversed by the ascorbate addition.

The conversion of pregnenolone to progesterone requires two enzymatic conversions: 1) the NAD-dependent oxidation of the hydroxyl group at the $\mathrm{C}-3$ position to a ketone by 3BHSOR and 2 ) the isomerization of the $\Delta_{5-6}$ double band to 
the $\Delta_{4-5}$ position. Although the reaction catalyzed by 3 BHSOR is known to be the rate limiting step in the coupled reaction (22), it is possible that ascorbic acid exerts its effect on the isomerase. Since the velocity of the 3BHSOR reaction depends upon the rapid removal of the $\Delta_{5} 3$-ketone intermediate, it is feasible that inhibition of the isomerase would result in the decreased conversion of PREG $\rightarrow$ PROG seen with hypovitaminosis $\mathrm{C}$. 
Figure 1. Michaelis Menton plot of 3BHSOR reaction in guinea pig testis microsomes with varying NAD. Incubations run in the presence of 10 MM PREG, .IM Tris, $\mathrm{pH} 7.4,5 \mathrm{mM} \mathrm{MgCl}_{2}, 1 \%$ propylene glycol at $37^{\circ} \mathrm{C}$ for 5 minutes. Protein- $60 \mathrm{~g} / .1 \mathrm{ml}$ final volume. NAD varied from $25-500 \mu \mathrm{M}$. $\mathrm{k}_{0.5} \mathrm{NAD}=35 \mu \mathrm{M}$. 
$\frac{3}{3}$
$\frac{0}{2}$

(6u/ulw/un) 5Odd 
Figure 2. Lineweaver-Burk replots of 3BHSOR with PREG as substrate in control and hypovitaminosis C guinea pig testis microsomes. Incubations were run in the presence of .IM Tris, $\mathrm{pH} 7.4$, $5 \mathrm{mM} \mathrm{MgCl} 2,500 \mu \mathrm{M} \mathrm{NAD}, 18$ propylene glycol at $37^{\circ} \mathrm{C}$ for 5 minutes. Protein-65 $\mathrm{\mu g}$ (control), $109+182 \mu \mathrm{g}$ (deficient) $\mathrm{k}_{0.5}=2.75 \mu \mathrm{M}$ (control) $3.3 \mu \mathrm{M}$ (deficient) $V_{\max }=.79 \cdot \mathrm{nm} / \mathrm{min} / \mathrm{mg}$ (control), $.28 \mathrm{~nm} / \mathrm{min} / \mathrm{mg}$ (deficient). 

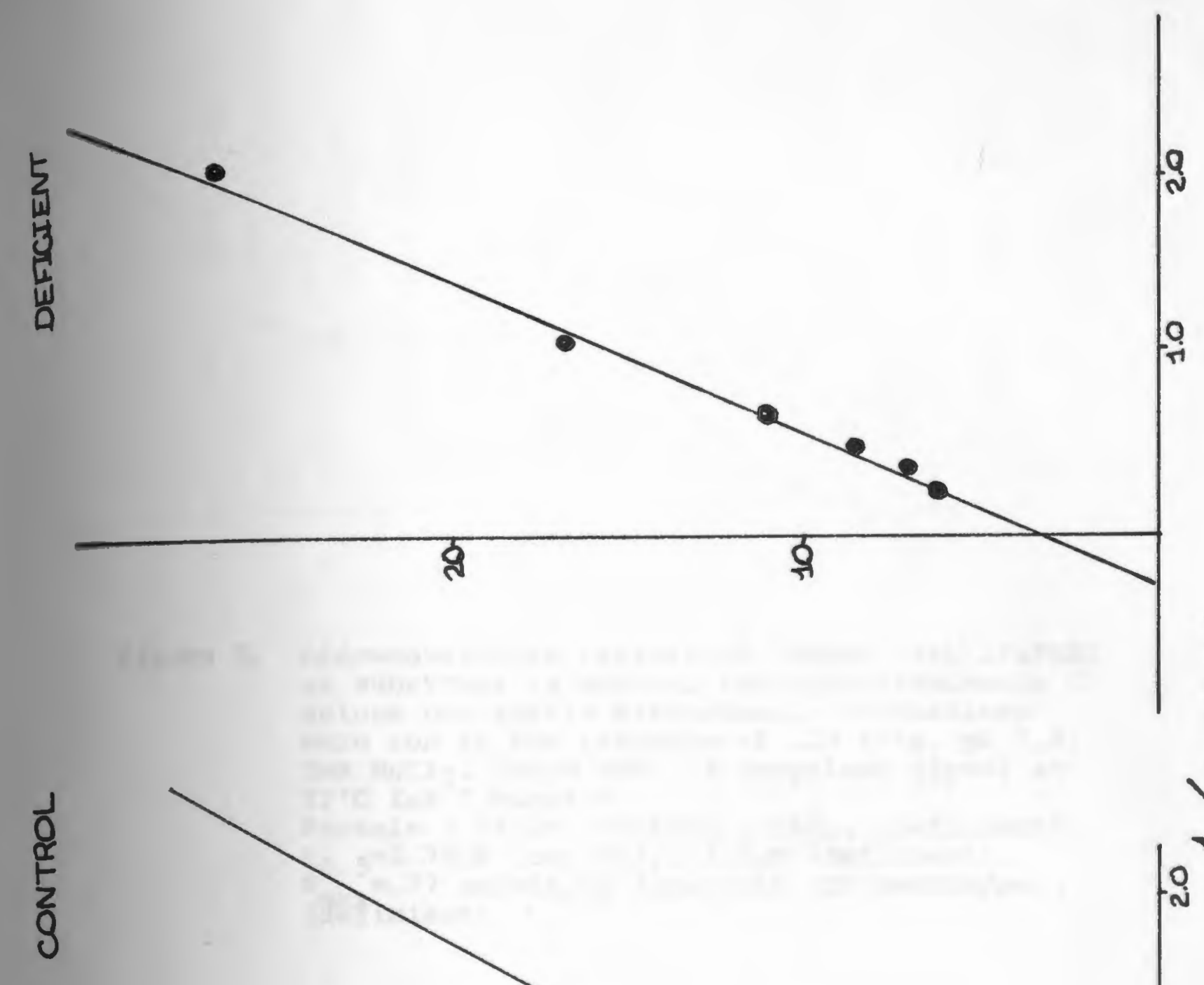

$\infty$
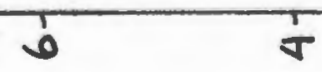

(bu/ulu/mu) sodd 
Figure 3. Lineweaver-Burk replots of 3BHSOR with $17 \alpha$ PREG as substrate in control and hypovitaminosis $\mathrm{C}$ guinea pig testis microsomes. Incubations were run in the presence of . IM Tris, $\mathrm{pH} 7.4$, $5 \mathrm{mM} \mathrm{MgCl}_{2}, 500 \mu \mathrm{M}$ NAD, $1 \%$ propylene glycol at $37^{\circ} \mathrm{C}$ for 5 minutes. Protein - 16lug (control), 162 $\mu \mathrm{g}$ (deficient) $\mathrm{k}_{0.5}=2.75 \mu \mathrm{M}$ (control), 3.3 $\mathrm{M}$ (deficient) $\mathrm{v}_{\mathrm{max}}=.77 \mathrm{~nm} / \mathrm{min} / \mathrm{mg}$ (control) $.28 \mathrm{~nm} / \mathrm{min} / \mathrm{mg}$ (daexicient). 
5
2
$H$
0
$H$
4
0

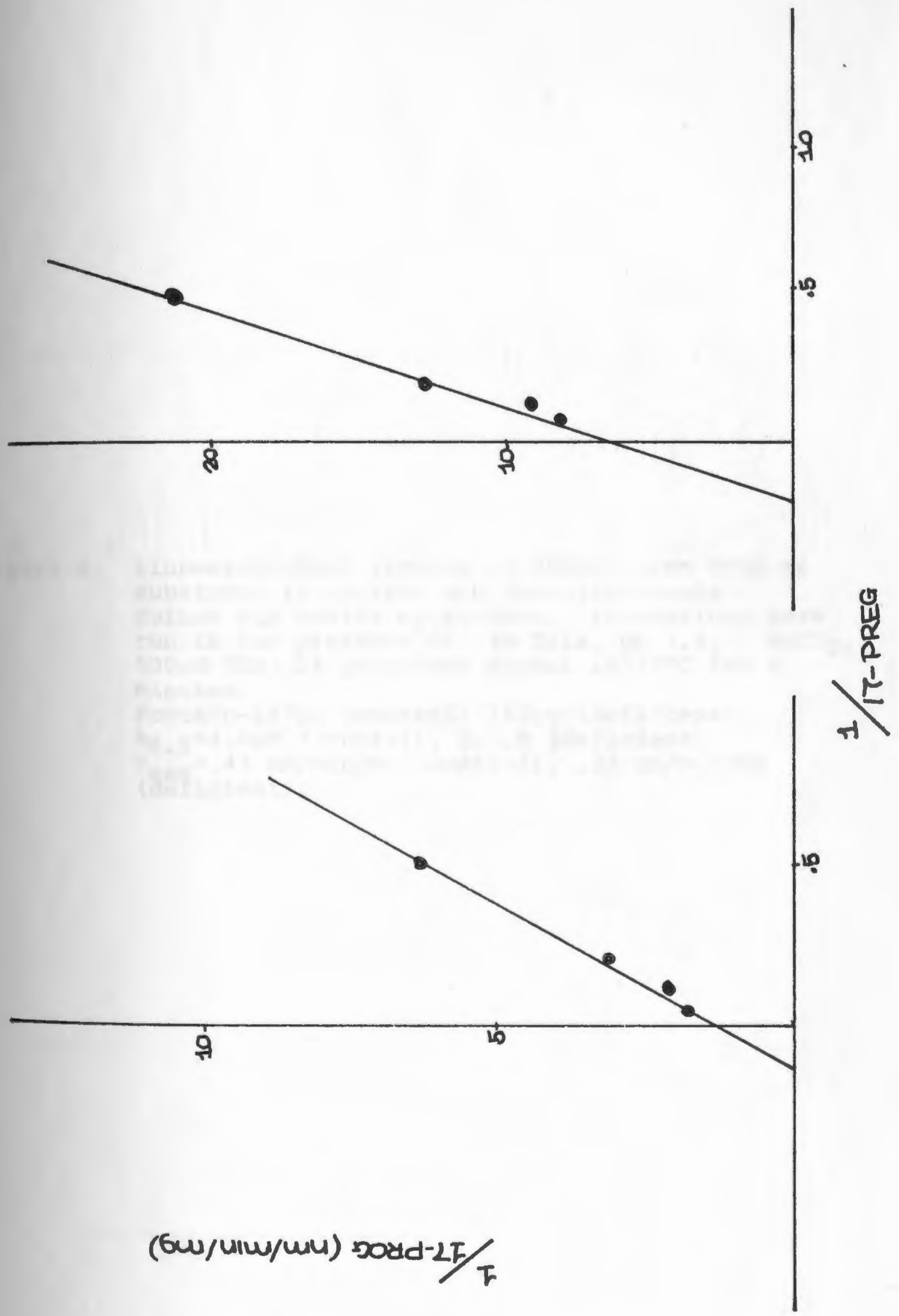


Figure 4. Lineweaver-Burk replots of 3BHSOR with DHEA as substrate in control and hypovitaminosis $C$ guinea pig testis microsomes, Incubations were run in the presence of . IM Tris, $\mathrm{pH} 7.4,5 \mathrm{MgCl}_{2}$, $500 \mu \mathrm{M} N A D, 18$ propylene glycol at $37^{\circ} \mathrm{C}$ for 5 minutes.

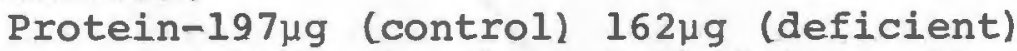

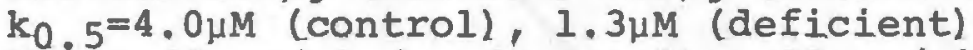

$\mathrm{V}_{\mathrm{max}}=.43 \mathrm{~nm} / \mathrm{min} / \mathrm{mg}$ (control), .22 nm/min/mg (deficient). 


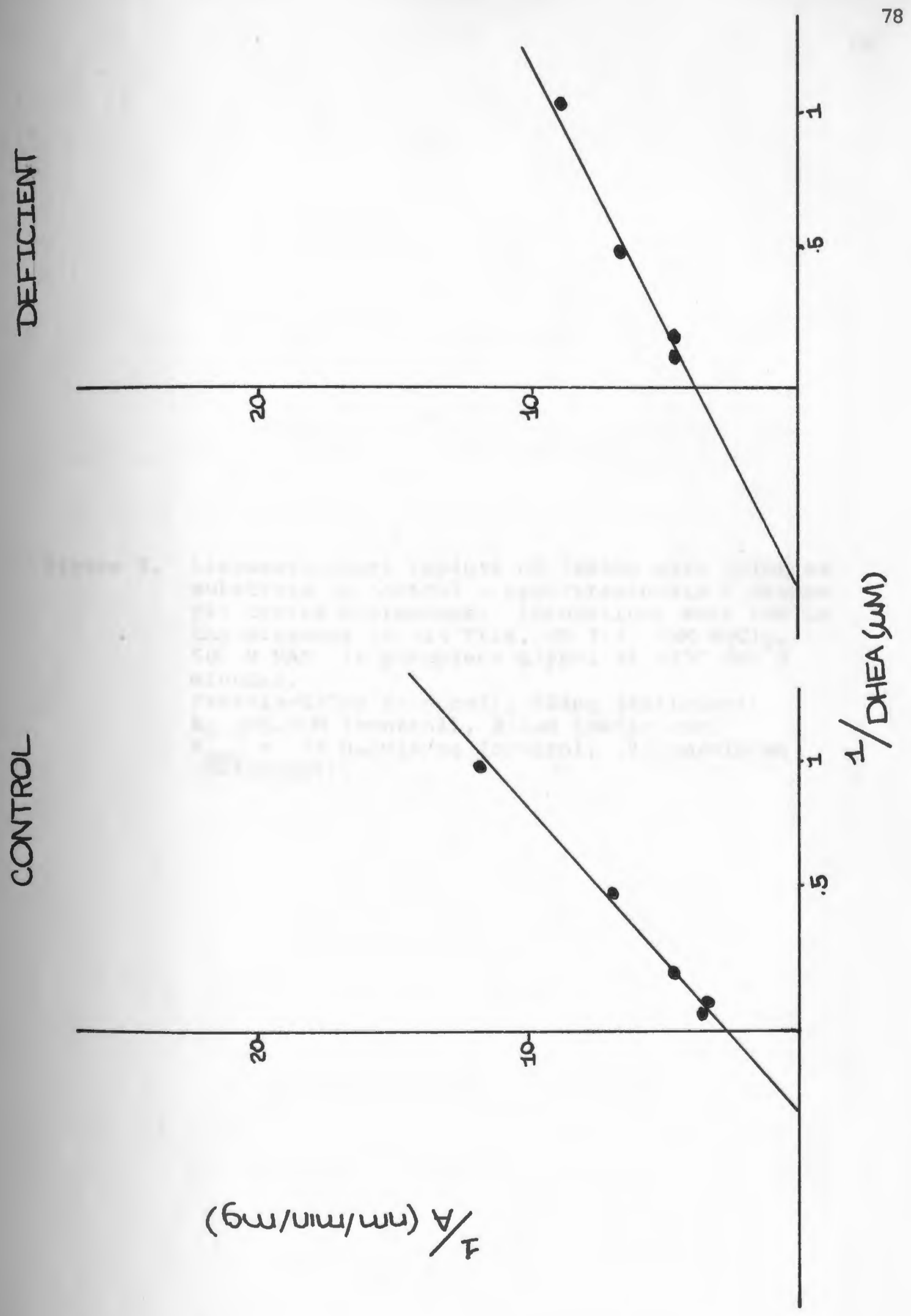


Figure 5. Lineweaver-Burk replots of 3BHSOR with ADIOL as substrate in control + hypovitaminosis $\mathrm{C}$ guinea pig testes microsomes. Incubations were run in the presence of .IM Tris, $\mathrm{pH} 7.4,5 \mathrm{mM} \mathrm{MgCl}_{2}$, $500 \mathrm{M}$ NAD, 18 propylene glycol at $37^{\circ} \mathrm{C}$ for 5 minutes.

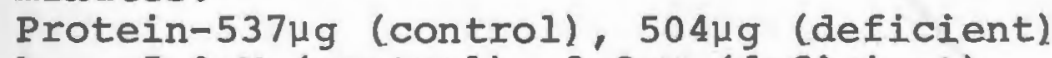
$\mathrm{k}_{0.5}=5.0 \mu \mathrm{M}$ (control), 3.8 $\mathrm{M}$ (deficient)

$\mathrm{v}_{\text {max }}=.35 \mathrm{~nm} / \mathrm{min} / \mathrm{mg}$ (control, .22 nm/min/mg (delicient). 

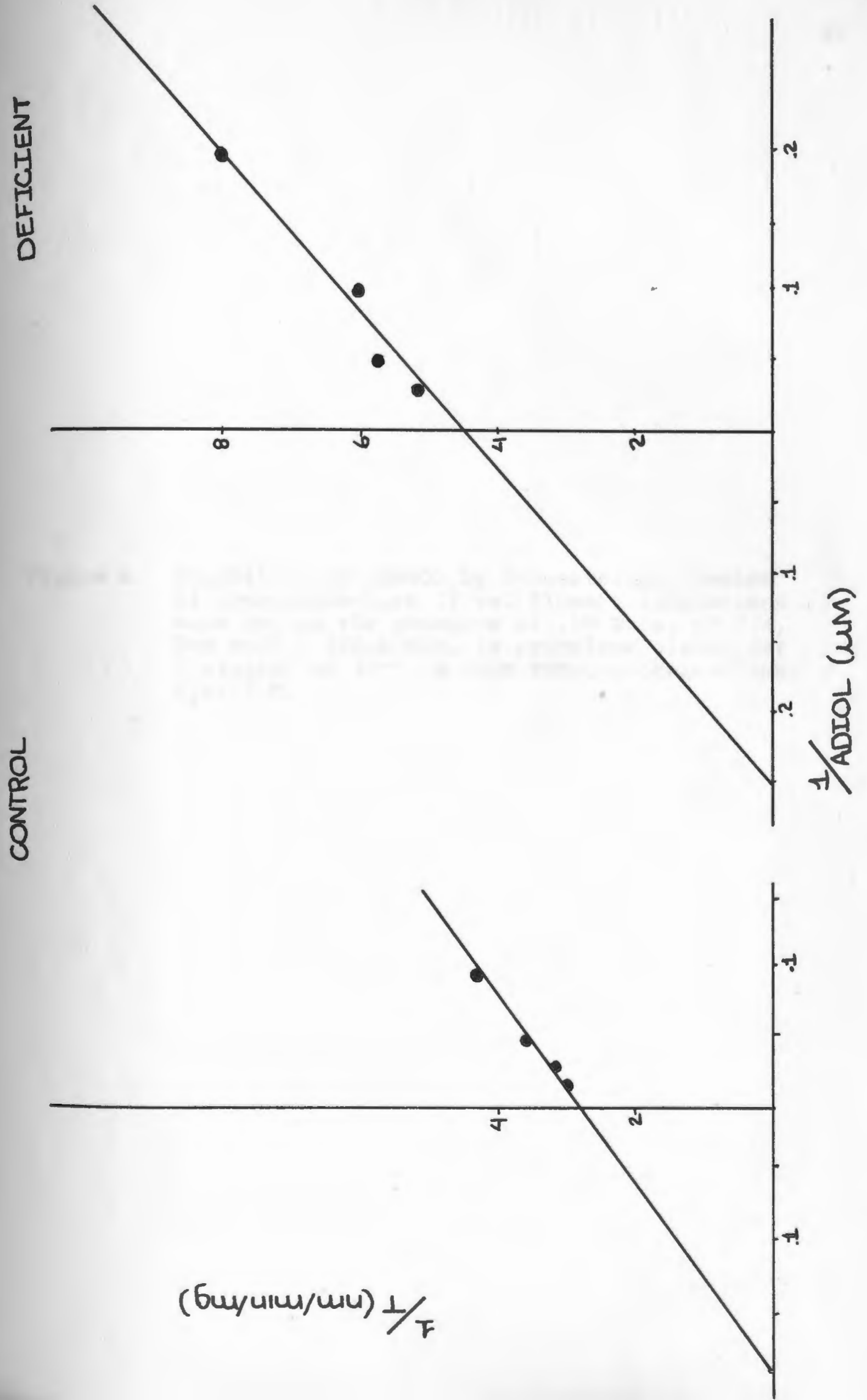
Figure 6. Inhibition of 3BHSOR by Progesterone, Replot of Lineweaver-Burk (I vs. Slope). Incubations were run in the presence of . IM Tris, $\mathrm{pH} 7.4$,

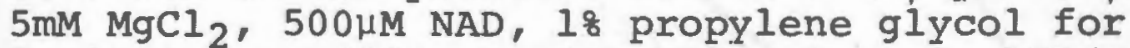
5 minutes at $37^{\circ} \mathrm{C}, 2-10 \mu \mathrm{M}$ PREG, Protein-173 $\mu \mathrm{g}$. $k_{i}=2.5 \mathrm{M}$. 
82

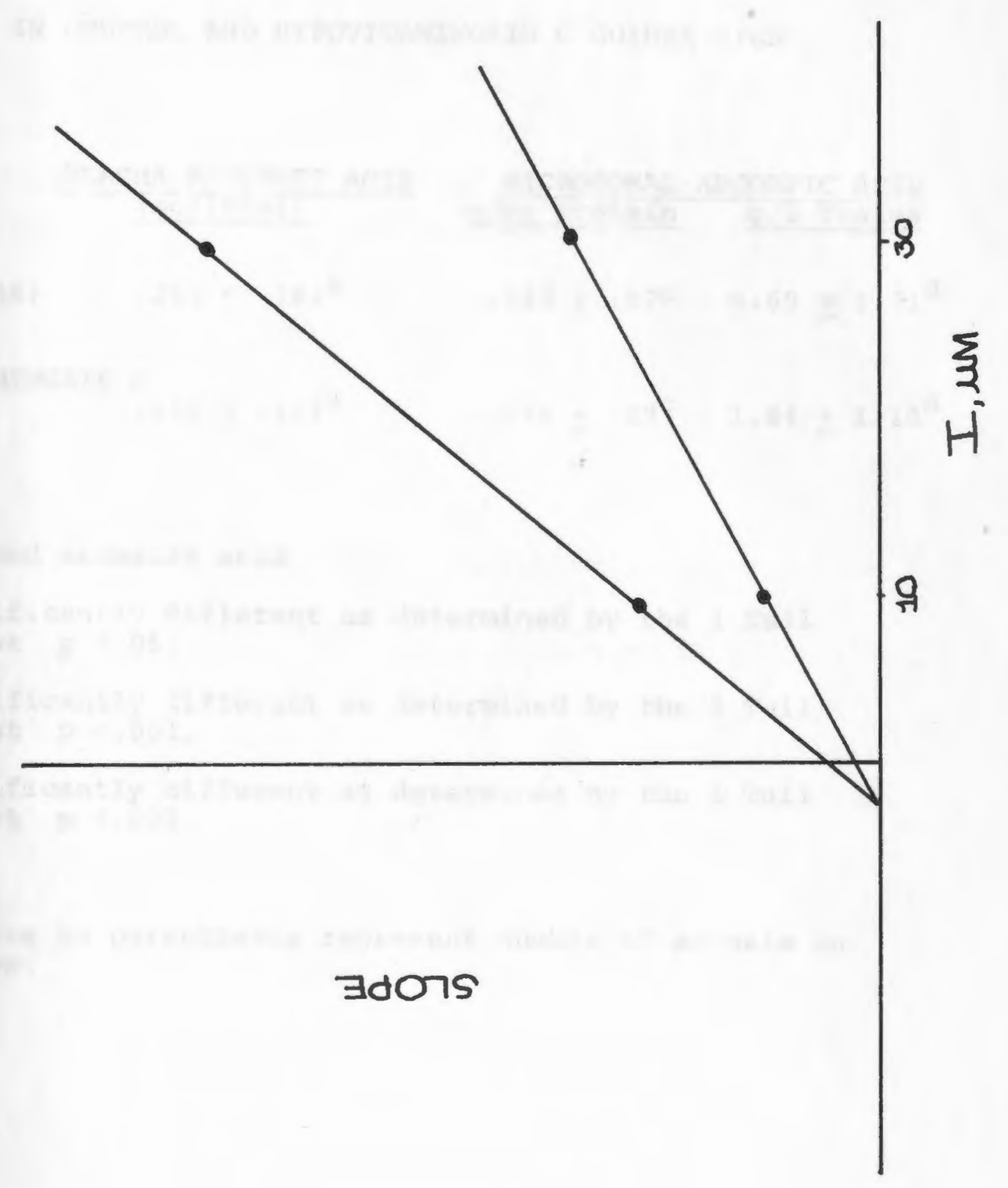




\section{TABLE I}

PLASMA AND TESTES MICROSOMAL ASCORBIC ACID ${ }^{a}$

LEVELS IN CONTROL AND HYPOVITAMINOSIS C GUINEA PIGS

$$
\frac{\text { PLASMA ASCORBIC ACID }}{\frac{(\mathrm{mg} / 100 \mathrm{ml})}{}}
$$

CONTROL (6)

HYPOVITAMINOSIS C

(6)

$$
.252 \pm .142^{b}
$$

$$
.152 \pm .101^{b}
$$

MICROSOMAL ASCORBIC ACID $\mathrm{g} / \mathrm{mg}$ protein $\mathrm{g} / 2$ Testes

$$
.323 \pm .07^{\mathrm{C}} \quad 6.69 \pm 1.71^{\mathrm{d}}
$$

$.072 \pm .07^{\mathrm{C}} \quad 1.84 \pm 1.10^{\mathrm{d}}$

a - reduced ascorbic acid

b - significantly different as determined by the 1 Tail T-Test $p<.05$.

c - significantly different as determined by the 1 Tail T-Test $p<.001$.

d - significantly different as determined by the 1 Tail T-Test $p<.001$

The numbers in parenthesis represent number of animals in each group. 
TABLE II

MEAN BODY WEIGHT, TESTES WEIGHTAND MICROSOMAL

PROTEIN IN CONTROL AND HYPOVITAMINOSIS C GUINEA PIGS

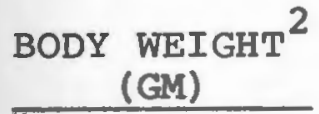

CONTROL (6) $714 \pm 81^{b}$

HYPOVITAMIN-

OSIS (6)

$$
617 \pm 134^{b}
$$

WEIGHT/2 TESTES (GM)

$4.25 \pm .55^{C}$

$20.63 \pm 1.22^{\mathrm{d}}$

$4.02 \pm .62^{\mathrm{C}}$
MICROSOMAL PROTEIN (MG/2 TESTES)
$25.77 \pm 1.85^{d}$

a - mean body weight after 9 weeks on experimental and control diets

b - values are significantly different as determined by the 1 Tail T-Test $p<.05$

c - values are not significantly different

d - values are significantly different as determined by the 2 Tail T-Test $p<.001$

The numbers in parenthesis represent the number of animals in each group. 
TABLE III

ACTIVITY OF 3BHSOR IN CONTROL AND HYPOVITAMINOSIS C GUINEA PIG TESTIS MICROSOMES

Reaction

$\mathrm{PREG} \rightarrow \mathrm{PROG}$

$17 \alpha \mathrm{PREG} \rightarrow 17 \alpha \mathrm{PROG}$

$\mathrm{DHEA} \rightarrow \mathrm{A}$

$\mathrm{ADIOI} \rightarrow \mathrm{T}$ $\underline{\mathbf{k}_{0.5}}$

2.75

5.5

4.0

5.0

HYPOVITAMINOSIS C

$\mathbf{k}_{0.5}$ expressed as $\mu \mathrm{M}$ substrate

$\mathrm{v}_{\max }$ expressed as $\mathrm{nm}$ product/min/mg protein 
TABLE IV

THE EFFECT IN VITRO ADDITION OF ASCORBIC ACID ${ }^{\mathrm{a}}$ AND DEHYDROASCORBIC ACID ON 3BHSOR ACTIVITY MICROSOMES OF GUINEA PIGS WITH HYPOVITAMINOSIS C

\begin{tabular}{|c|c|c|c|c|c|c|}
\hline \multirow{2}{*}{$\begin{array}{c}\text { Substrate } \\
\text { Concentration } \\
(\mu \mathrm{M})\end{array}$} & \multicolumn{3}{|c|}{+ Ascorbic ACid } & \multicolumn{3}{|c|}{ + Dehydroascorbic Acid } \\
\hline & $108 \mu \mathrm{g}$ & Protein & $297 \mu \mathrm{g}$ & Protein & $297 \mu \mathrm{g}$ & Protein \\
\hline 1.0 & & 100 & 10 & 0 & & - \\
\hline 2.0 & & 134 & 10 & 7 & & 47 \\
\hline 5.0 & & 123 & 16 & 55 & & 55 \\
\hline 10.0 & & 112 & 15 & 56 & & 47 \\
\hline 15.0 & & 100 & & 3 & & - \\
\hline
\end{tabular}

a - final concentration, 2mM Ascorbic Acid or Dehydroascorbic Acid

b - PREG used as substrate

c - Reference - pooled microsomes from hypovitaminosis C guinea pigs - no addition 


\section{References}

1. Sulimovici, S. and Boyd, G.S. (1968) Eur. J. Biochem. 3, 332 .

2. Sulimovici, S. and Boyd, G.S. (1968) steroids 12, 127.

3. Shimuzu, K. (1970) Biochim. Biophys. Acta 210, 333.

4. Kitabchi, A.E. (1967) Steroids 10, 567.

5. Cooper, D.Y. and Rosenthal, O. (1962) Arch. Biochem. Biophys. 96,331 .

6. Jenkins, P. (1967) Endocrinology 70, 267.

7. Pankov, Y.A. (1966) Fed. Proc. 25, T268.

8. Jones, R.S., Peric-Goleu, L. and Eik-Nes, K. (1958) Endocrinology 63, 659 .

9. Gombe, S., Odvor-Okelo, D., Bharaj, B. and Verjee, Z.H. (1977) In. J. Vit. Nutr. Res. 47, 75.

10. Bacchus, H. (1957) Am. J. Physiol. 188, 303.

11. Gruber, K.A., Obrien, L.V. and Gerstner, R. (1976) Science 191,472 .

12. Koritz, S.B. (1963) Arch. Biochem. Biophys. 100, 349.

13. Staudinger, H.K., Krish, K. and Leonhauser, A. (1961) Ann. N.Y. Acad. Sci. 22, 295.

14. Heath, H. and Fiddick, R. (1965) Biochem. J. 94, 114 .

15. Bielski, B.H.J. and Richter, H. (1975) Ann. N.Y. Acad. Sci. $258,231$.

16. Biswas, N.M. (1969) Endocrinology 85, 981.

17. Devine, M.M. and Rivers, S.M. (1968) J. Nutr. 97, 295.

18. Zannoni, V.G., Lynch, M., Goldstein, s. and Sato, P. (1974) Biochem. Med. 11, 41.

19. Association Official Analytical Chemists, Official Methods of Analysis (1980), 13th ed. Washington, D.C., P. 746 .

20. Lineweaver, H. and Burk, D. (1934) J. Am. Chem. Soc. 56, 658. 
21. Osterling, M.J. and Long, C.N.H. (1951) Science 113, 241.

22. Fan, D. and Troen, P. (1975) J. Clin. Endocrinol. 41, 563 .

23. Purvis, J.L., Canick, J.A., Latif, S.A., Rosenbaum, J.H., Hologgitas, J. and Menard, R.H. (1973) Arch. Biochem. Biophys. 159,39 .

24. Degwitz, Z., Walsh, E., Dubberstein, M. and Winter, J. (1975) Ann. N.Y. Acad. Sci. 258, 201. 


\section{HISTORICAL}

\section{ANDROGEN BIOSYNTHESIS IN THE TESTIS}

Synthesis of testosterone from acetate was shown to involve cholesterol, pregnenolone, progesterone, 17ahydroxyprogesterone and androstendione (1). Two pathways for the synthesis of testosterone from cholesterol have been subsequently identified. Slaunwhite and Samuels (2) demonstrated a pathway in rat testes homogenates in which progesterone was hydroxylated at the 17 position followed by side chain cleavage to produce androstendione which is reduced to form testosterone. Neher and Wettstein (3) found dehydroepiandrosterone to be an intermediate in testosterone synthesis in porcine testes homogenates and suggested a pathway in which pregnenolone is converted to 17ahydroxypregnenolone and then to DHEA. DHEA was presumed to be converted to androstendiol and then reduced to testosterone. Eik-Nes and Kekre (4) confirmed DHEA to be an intermediate in dog testes. Later, $\Delta_{5}$-androstendiol was identified as a probable intermediate in the conversion of DHEA to testosterone in rabbit (5) and rat (6) testis microsomes. Hagen and Eik-Nes demonstrated the conversion of 17ahydroxypregnenolone to 17ahydroxyprogesterone, the first alternate route to testosterone from pregnenolone.

The specific enzyme reactions have been further elucidated. The first reaction in adrenal steroid synthesis and 
of the $\Delta_{4}$ pathway in the testis is the $3 B$ oxidation of pregnenolone, catalyzed by $3 \mathrm{~B}$ hydroxysteroid oxidoreductase $/ \Delta_{5}-3-$ ketosteroid isomerase. The reaction involves an NAD dependent oxidation at $C_{3}$ to yield a $\Delta_{5}$-3-ketosteroid intermediate which is isomerized to progesterone, a $\Delta_{4}-3$-ketosteroid. The oxidation is rate limiting in the reaction (8) and the overall reaction rate is determined by the rate of conversion of the $\Delta_{5}$-3-hydroxysteroid to the $\Delta_{5}-3-k e t o s t e r o i d$. The reaction is largely irreversible. This is probably attributable to the isomerization step in the coupled reaction, although the conversion was shown to be reversible in the rabbit (9) and ovine adrenal microsomes (10).

The next reaction on either the $\Delta_{4}$ or the $\Delta_{5}$ pathway is the 17ahydroxylation of PROG or PREG which is catalyzed by a cytochrome-P-450 dependent hydroxylase. The enzyme is of the mixed-function oxidase type and requires molecular oxygen and NADPH. Purvis et al. have demonstrated the P-450 dependence in hypophysectomized rats (11). In the testes microsomes of the hypophysectomized animal, the decay rate of the $17 \alpha$ hydroxylase activity, ( $1 / 2=2.3$ days), paralleled the decay of cytochrome $\mathrm{P}-450$, (t $1 / 2=3.3$ days). Conversely, the hydroxylase was shown to maintain a constant activity per nanomole of cytochrome P-450 when the level of P-450 was increased under HCG stimulation. Further evidence that the enzyme requires cytochrome P-450 is inhibition of the $17 \alpha$-hydroxylase activity by carbon monoxide $(10,11)$ and 
Pironolactone (14) which are known to be inhibitors of cytochrome P-450.

Metabolism of $17 a$-hydroxysteroids to testosterone involves a second cytochrome-P-450 dependent conversion, catalyzed by $\mathrm{C}_{17}-\mathrm{C}_{20}$ lyase. The reaction requires NADPH and molecular oxygen. As with the P-450 dependent steroid 17ahydroxylase, $C_{17}-C_{20}$ lyase levels parallel the cytochrome P-450 content of the testes microsomes (II). The reaction has been found to be irreversible (15). Products of $\mathrm{C}_{17}-\mathrm{C}_{20}$ lyase reaction are $\mathrm{C}_{19}$-ketosteroids which are reduced at $\mathrm{C}_{19}$ to testosterone. The reaction is catalyzed by $17 \mathrm{~B}$-hydroxysteroid oxidoreductase. The enzyme requires NADPH but does not involve cytochrome P-450. The decay rate of $17 \mathrm{BHSOR}$ was found to be slower in testis microsomes of hypophysectomized rats, ( $1 / 2=4.5$ days), than either cytochrome $\mathrm{P}-450$ or the P-450 dependent enzymes (II) and enzyme activity is not inhibited by spironolactone (14). The reaction is capable of proceeding in both forward and reverse directions, however, there is some evidence that the oxidation of $\mathrm{T} \rightarrow \mathrm{A}$ and the reduction of $A \rightarrow T$ are catalyzed by two distinct enzymes $(16,17,18)$.

Although, the $\Delta_{4}$ and $\Delta_{5}$ pathways for steroid biosynthesis are fairly well defined, the number of enzymes involved in the catalysis of the reactions remains controversial. It has been shown that 3-(17) BHSOR purified from Pseudomonas testeroni yields 4 distinct bands upon electrophoretic 
separation, each possessing both $3 \mathrm{~B}$ and 17BHSOR activity (19). Two subunits were demonstrated and the enzyme was believed to exist as four tetrameric species. However, Shikita and Talalay reported all 3BHSOR activity to be associated with a single band upon electrophoretic separation of the purified P. testeroni enzyme $(30)$. No evidence exists for the presence of multiple forms in mammalian species. $3 \mathrm{BHSOR} / \mathrm{A}_{5}-3-$ ketoisomerase has been isolated from sheep (2I) and human (22) adrenal cortex microsomes and found to have similar activity with either DHEA or pregnenolone as substrate. Yates and Deshplande (22) noted that when both substrates were incubated simultaneously, the $k_{m}$ value decreased $50 \%$ and the $V_{\max }$ decreased suggesting that the two substrates were competing for the same enzyme. In human testis microsome (23), the $k_{m}$ for DHEA and androstendiol were found to be similar and the two substrates were shown to be competitive inhibitors of one another providing further evidence that the various substrates of $3 B H S O R$ all compete for the same enzymatic site.

The existence of two $C_{17}-C_{20}$ lyases, or, two catalytic sites for 17\%'REG and 170PROG was demonstrated In human testes microsomes (24). $\mathrm{K}_{\mathrm{m}}$ values were found to be different for 17 aPROG, ( $\left.1.7 \times 10^{-5} \mathrm{M}\right)$, and $17 \alpha \mathrm{PREG},\left(5.9 \times 10^{-7} \mathrm{M}\right)$. Additionally, testosterone was shown to be a competitive inhibitor with 170PROG as substrate and uncompetitive with respect to 17aPREG, indicating that $T$ binds to the active site 
on the PROG enzyme and at other than the active site on the PREG enzyme. However, this evidence cannot be considered definitive as 17 aPROG and $17 \propto \mathrm{PREG}$ were found to act as competitive inhibitors of one another. Recently, a homogenous tochrome P-450 was purified from neonatal pig testis microsomes $(25,26)$. Both lyase and 17 ahydroxylase activities were found to be associated with this enzyme. The $k_{m}$ values were similar for both $17 \alpha$ PROG and PROG although the $v_{\max }$ for the hydroxylation was twice as great as the lyase. Both activities were reported to be inhibited to the same extent by p-450 inhibitors. These findings are in contrast to those of Betz (27) who demonstrated that the enzyme activities are associated with two different proteins in rat testis microsomes. The question as to the number of enzymes is crucial to understanding the varying pathways for testosterone synthesis. Two major pathways, the $\Delta_{4}$ pathway from pregnenolone to progesterone and the $\Delta_{5}$ pathway from pregnenolone to $17 \alpha$ maxyprogesterone have been widely accepted. It appears, however, that some species use mixed, (or alternate), pathways to $T$. The existence of a single lyase and steroid hydroxylase would limit the use of mixed pathways since the 17 hydroxy product of the first $\Delta_{5}$ reaction would likely be enzyme-bound and not available for the alternate pathways prior to the lyase reaction.

The mixed pathways in rat and rabbit testes have been shown using an in vivo perfusion technique $(28,29,30)$. The 
most probable pathways in the rat were predicted to be mixed: PREG $\overrightarrow{\Delta_{s}} 17$ aPREG $\rightarrow 17$ PROG $\underset{\Delta \overrightarrow{4}}{\rightarrow} A_{\Delta_{4}}^{*} T$, or, purely $\Delta_{4}:$ PREG $\rightarrow$ PREG $\rightarrow 17$ QPROG $\rightarrow \mathrm{A} \rightarrow \mathrm{T}$. The rabbit is capable of using mixed pathways: PREG $\rightarrow 17 \alpha$ PREG $\rightarrow 17 \alpha$ PROG $\rightarrow \mathrm{A} \rightarrow \mathrm{T}$ or $\Delta_{5}:$ PREG $\rightarrow 17 \alpha$ PREG $\rightarrow$ DHEA $\rightarrow$ ADIOL $\rightarrow$ T but was predicted to favor the $\Delta_{5}$ pathway due to low conversion of $17 \propto \mathrm{PROG} \rightarrow \mathrm{A}$.

Testosterone biosynthesis on the human has been assumed to rely primarily on the $\Delta_{5}$ pathway from PREG $\rightarrow 17$ aPREG $\rightarrow$ $\mathrm{DHEA}+\mathrm{ADIOL}+\mathrm{T}(31,32)$. Very low conversion of DHEA $\rightarrow \mathrm{A}$ was seen in comparison to the large conversion of DHEA $\rightarrow$ ADIOL so the possible use of a mixed pathway from PREG $\overrightarrow{\Delta \overrightarrow{5}} 17 \alpha$ PREG $\overrightarrow{\Delta 5}$ DHEA $\rightarrow A_{\Delta \overrightarrow{4}} T$, was not considered to be favorable. The $\Delta_{5}$ pathway was found to predominate in the dog by in yiyo $(33,34)$ and in vitro (35) methods. The alternate pathway from DHEA $\rightarrow \mathrm{A} \rightarrow \mathrm{T}$ is unlikely in the dog since DHEA $\rightarrow$ 3BHSOR activity was found to be only 15\% that of DHEA-17BHSOR (35). Although differences in total steroid secretion among species under maximum stimulation may be accounted for on a basis of testes weight (36) or leydig cell mass (30), differences in testosterone secretion are not related to differences in these two values. It has been suggested by zirkin et al. (37), that quantitative differences in testosterone production by maximally stimulated testes on the hamster, rat, rabbit, dog, and guinea pig may be explained on the basis of leydig cell ultrastructure. A linear relationship was shown between the amount of leydig cell smooth endoplasmic reticulum and testosterone production. As most of the 
stweroidogenic enzymes are localized in the SER it appears reasonable that the total amount of this organelle would reflect the steroid synthesizing capacity of the organism. However, the amount of SER enzymes have not been quantitated and it appears plausible that differences in testosterone synthesis among species are related to enzymatic activities of the $\Delta_{4}, \Delta_{5}$ or mixed pathways and the efficiency of feedback and feedforward controls on these pathways.

II. THE EFFECT OF ASCORBIC ACID ON 3B-HYDROXYSTEROID OXIDOREDUCTASE IN THE TESTIS.

Administration of large doses of ascorbic acid has been linked to abortion in animals $(38,39,40)$ and, possibly, humans $(40)$. It has been proposed that the inability to maintain a pregnancy after ingestion of massive doses of ascorbic acid is due to a disruption in steroid metabolism leading to alterations of steroid hormone levels in the : blood. The importance of progesterone, in the maintenance of pregnancy has long been recognized. Progestogens are frequently used in the maintenance of pregnancies in females with histories of repeated abortions.

The role of ascorbic acid in steroidogenesis is poorly understood. High levels of ascorbic acid have been shown to inhibit the conversion of cholesterol to pregnenolone; this is considered to be the rate limiting step in the biosynthesis of steroids. Conversion of the C-27 steroid, cholesterol, to $\mathrm{c}-21 \Delta_{5}$-pregnenolone involves two mitochondrial 
hydroxylations at $\mathrm{C}-20$ and $\mathrm{C}-22$, followed by side chain cleavage between C-20 and C-22 (41). In vitro studies, using levels of ascorbic acid comparable to those of resting ovary and adrenal cortex, have demonstrated ascorbate inhibition of mitochondrial side chain cleavage in rat ovary $(42,43)$ and bovine adrenal cortex (44). Stimulation of steroidogenesis in the ovary by IH and in the adrenal cortex by ACTH results in decreased ascorbic acid concentrations in these tissues before steroid synthesis begins (45). Presumably, this releases the inhibition on the conversion of cholesterol to pregnenolone. Steroid synthesis proceeds in one of two directions, via the 4 pathway which involves a conversion of the $\Delta_{5} 3$-hydroxysteroid, pregnenolone, to the $\Delta_{4}$ 3-ketosteroid, progesterone, by action of the enzymes P-Hydroxysteroid oxidoreductase and $\Delta_{4}$ 3-ketosteroid isomerase, or, by use of the $\Delta_{5}$ pathway through 17k-hydroxypregnenolone. Depressed conversion of $\Delta_{5}$-hydroxysteroids to $\Delta_{4}$-ketosteroids has recently been observed in vitamin C deficient guinea pigs (46). Decreased ability to convert 3B-hydroxysteroids to 3-ketosteroids has been seen in Vitamin A deficient rats (47). The Vitamin A deficient rat is unable to synthesize ascorbic acid. When animals were depleted of Vitamin A and Vitamin C was removed from the diet, decreased 3BHSOR activity was seen. Normal activity was achieved by restoration of ascorbic acid. Dehydroascorbate was 
shown to stimulate the conversion of pregnenolone to progesterone in toad testes (48).

The results of these studies suggest that ascorbic acid should favor the $\Delta_{4}$ pathway. However, in vitro incubations of guinea pig ovary and testis homogenates have shown that the addition of . $5 \mathrm{mM}$ ascorbic acid stimulated the conversion of $\Delta_{5}$ to $\Delta_{4}$ steroids from cholesterol to a greater extent than additions at 1.0 or $1.5 \mathrm{mM}$ levels and that the stimulatory effect was absent at $2 \mathrm{mM}$ ascorbate (49). No significant increase in the synthesis of $\Delta_{4}$ steroids could be seen when pregnenolone was used as substrate in the presence of $0, .5,1.0,1.5$ and $2.0 \mathrm{mM}$ ascorbate (49). All levels of ascorbic acid were shown to inhibit 17 hydroxylation (49). Ascorbic acid has been shown to inhibit 17ahydroxy-corticosteroid production in the presence of $\mathrm{ACTH}$ in beef adrenal cortex preparations (50) and to favor the production of 17Reoxycorticosteroids in pig adrenal cortex microsomes (51). Microsomal 21-hydroxylase activity was inhibited by ascorbic acid in bovine adrenal cortex $(52,53)$.

It has been proposed that ascorbic acid may release $\mathrm{NADH}$ inhibition of $3 B H S O R$ in the conversion of pregnenolone to progesterone (54). The reversal of $\mathrm{NADH}$ inhibition is presumed to involve an ascorbate dependent NADH oxidation. Staudinger (55) has demonstrated a microsomal NADH-oxidase in rat liver which is strictly specific for ascorbic acid. The following reaction pathway was proposed: 


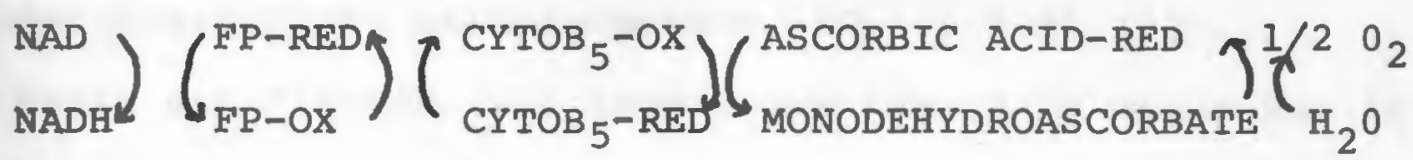

The flavoprotein was found to be cyanide insensitive and therefore was not NADP: ferricytochrome $b_{5}$ oxidoreductase. The protein was later identified to be ascorbate:ferricytochrome $\mathrm{b}_{5}$ oxidoreductase (EC 1.10.2.1) (56). Existing evidence suggests that most ascorbic acid oxidations follow the : two-step process described by Michaelis (57) involving the formation of free radical intermediates. Monodehydroascorbate may be formed by the action of $\ell$-ascorbate:oxygen oxidoreductase (EC 1.1.0.3.3), or, by the comproportionating reaction as shown below:

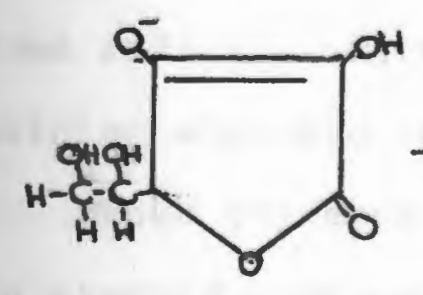

Ascorbate

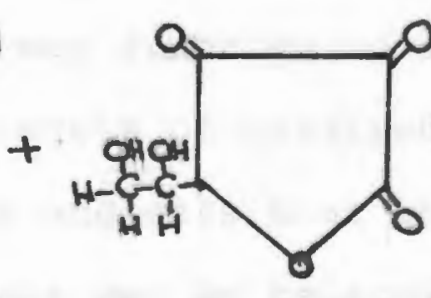

Dehydroascorbate

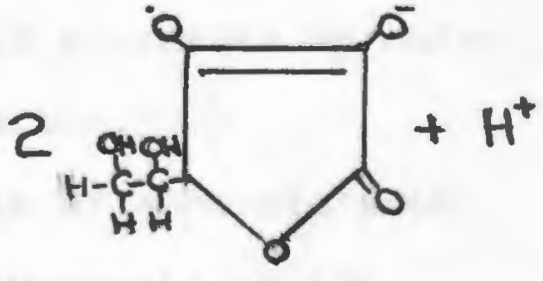

Monodehydroascorbate

The monodehydroascorbate free radical formed by comproportionation:is equally effective as substrate for NADH linked electron transport as the free radical formed on the enzyme catalyzed reaction. However, the removal of electrons from NADH via monodehydroascorbate need not necessarily'be linked to cytochrome $b_{5}$. In liver microsomes only 108 of the electrons transported from $\mathrm{NADH}$ to monodehydroascorbate utilize cytochrome $b_{5} ; 908$ of the electrons are transferred by NADH: 
wonodehydrascorbate oxidoreductase (EC 1.6.5.4) (54).

Heath and Fiddick (58) have shown that NADH oxidation in bovine occular tissue microsomes is stimulated by ascorbic acid and that dehydroascorbic acid could not substitute for the reduced form. Devine and Rivers (59) found depressed ratios of NAD/NADH in tissues of ascorbic acid deficient guinea pigs which could be attributed to increased levels of $\mathrm{NADH}$, although the activity of the ascorbic acid dependent NADH oxidase was not impaired on the vitamin $C$ deficient guinea pig.

The physiological role of the NADH-monodehydroascorbate pidoreductases is unclear. It was presumed that this mechanism may conserve ascorbic acid by reducing formation of the free radical, or, may function in steroid synthesis by maintaining adequate levels of oxidized cofactor.

Other evidence suggests that the role of ascorbic acid in steroid synthesis may be related to synthesis of the ferricytochromes, P-450 and $\mathrm{b}_{5}$. Liver cytochrome P-450 and $\mathrm{b}_{5}$ levels were found to decrease in ascorbic acid deficient guinea pigs $(60)$. Twenty-eight days after withdrawal of ascorbic acid, cytochrome P-450 levels were $30 \%$ of control and $b_{5}$ decreased to $45 \%$ of control levels. Liver ascorbic acid was found to drop rapidly during the initial 14 days of depletion and then to level off. P-450 had decreased to $45 \%$ of control and $b_{5}$ to $70 \%$ at 14 days but continued to fall after ascorbic acid levels had stabilized. Similar, 
but less dramatic, results were seen in the adrenal (60). 3tochrome P-450 levels could be normalized with ascorbic acid administration but this normalization was abolished by Inhibitors of protein synthesis unless $\delta$-amino levulonic acid was administered concurrently. Additionally, phenobarbital or a-methylcholanthrene, known stimulators of heme synthesis, were able to restore P-450 levels in vitamin C deficient animals (61). This evidence suggests that heme synthesis is Impaired in ascorbic acid deficiency.

Testes levels of ascorbic acid have been determined in the rat $(62)$, guinea pig $(63,64)$ and human $(65)$. The normal level in the human testis is the lowest cited $(3 \mathrm{mg} / 100 \mathrm{gm}$ tissue), whereas, higher levels have been reported in the guinea pig (24-36 mg/100 gm tissue), and rat, (25-30 mg/100 gm tissue). Testes ascorbic acid concentrations decrease in scorbutic animals with the degree of depletion apparently being related to the stage of scurvy. Levels of $6 \mathrm{mg} / 100 \mathrm{gm}$ tissue in early scurvy were decreased to $3 \mathrm{mg} / 100 \mathrm{gm}$ tissue in late scurvy (63). Gombe et al. (64) reported testes levels of $8.4 \mathrm{mg} / 100 \mathrm{gm}$ tissue after depletion for three weeks but found no corresponding decrease in plasma or testes testosterone levels. This data was in contrast to that of Kocen and Cavazos (66) who reported arrest of spermatogenesis in ascorbic acid deficient guinea pigs and in agreement with Jones et al. (67) who found no inhibition of steroid synthesis in the adrenals of scorbutic guinea pigs. Cholesterol 
levels in the testes were significantly decreased in the testes of scorbutic guinea pigs (64) suggesting release of inhibition on the cholesterol side chain cleavage enzymes by decreased ascorbic acid levels. This evidence supports the inhibitory role of ascorbic acid in steroid synthesis proposed by sulimovici $(42,43)$ and others $(44,45,52,53)$. 
References

1. Dorfman, R.I., Forchielli, E. and Gut, M. (1963) Recent Progr. Hormone Res. 19, 258.

2. Slaunwhite, W.R. and Samuels, L.T. (1956) J. Biol. Chem. 220,341 .

3. Neher, R. and Wettstein, A. (1961) Acta Endocrinol, 35, 1.

4. Eik-Nes, K.B. and Kekre, M. (1963) Biochim. Biophys. Acta 78, 449 .

5. Rosner, J.M, Horitz, S. and Forsham, P.H. (1964) Endocrinology $75,229$.

6. Slaunwhite, W.R. and Burgett, M.J. (1965) Steroids $\underline{6}$. 721.

7. Hagen, A.A. and Eik-Nes, K.B. (1964 ( Biochim. Biophys. Acta 86, 372 .

8. Fan, D. and Troen, P. (1975) J. Clin. Endocrinol. 41, 563.

9. Rosner, M., Hall, P.F. and Eik-Nes; K.B. (1965) Steroids 5, 199 .

10. Ward, M.G. and Engel, L.L. (1966) J. Biol. Chem. 241, 3147 .

11. Purvis, J.L., Canick, J.A., Latif, S.A., Rosenbaum, J.H., Hologgitas, J. and Menard, R.H. (1973) Arch. Biochem. Biophys. 159,39 .

12. Imai, Y. and Sato, R. (1974) Biochem. Biophys. Res. Comm. 60,8 .

13. Arine, E. and Philpot, R.M. (1976) J. Biol. Chem. 251, 3213.

14. Menard, R.H., Stripp, B. and Gillette, S.R. (1974) Endocrinology 94, 1628 .

15. Hall, P.F. In: The Testis, edited by A.D. Johnson and W.R. Gomes. New York: Academic Press, 1970 Vol. 1 p. 1-71.

16. Bogovich, K. and Payne, A.H. (1978) Fed. Proc. 37, 1579.

17. May, J.V., Hologgitas, J. and Purvis, J.L. (1978) Fed. Proc. 37,1474 . 
18. May, J.V., Ph.D. Dissertation. (1978) University of Rhode Island.

19. Schultz, R.M., Groman, E.V. and Engel, L.I. J. Biol. Chem. 252, 3775.

20. Shikita, M. and Talalay, P. (1979) Anal. Biochem. 95, 286.

21. Ford, H.C. and Engel, L.L. (1974) J. Biol. Chem. 294, 1363.

22. Yates, J. and Deshpande, N. (1975) J. Ehdocrinology 64, 195.

23. Oshima, F., Fan, D. and Troen, P. (1980) J. Clin. Endocrinol. Metab. 40,540 .

24. Hosaka, M., Oshima, H. and Troen, P. (1980) Acta. Endocrinol. 94, 389 .

25. Nakajin, S. and Hall, P.F. (1981) J. Biol. Chem. 256, 3871 .

26. Nakajin, S., Shively, J.E., Yuan, P. and Hall, P.F. (1981) Biochem. 20, 4037.

27. Betz, G., Tsai, P. and Weakley, P. (1976) J. Biol. Chem. 251, 2839.

28. Becker, S., Chubb, C. and Ewing, L. (1980) Am. J. Physiol. 239, Rl84.

29. Chubb, C. and Ewing, L. (1979). Am. J. Physiol. 237. E247.

30; Ewing, L.I., Cochran, R.C., Zirkin, R. and Chubb, C.E. (1980) In: Testicular Development Structure and Function edited by $A$. Steinberger and E. Steinberger, Raven Press, New York, p. 117-176.

31. Takumi, Y. and Troen, P. (1972) J. Clin. Endocrinol. Metab. 34, 783 .

32. Takumi, Y. and Troen, P. (1972) J. Clin. Endocrinol. Metab. 34, 793.

33. Eik-Nes, K. and Kekre, M. (1963). Biochim. Biophys. Acta 78, 449 .

34. Van Der Molen, H.J. and Eik-Nes, K. (1971) Biochim. Biophys. Acta 248, 343. 
35. Hologittas, J., Ph.D. Dissertation (1981) University of Rhode Island, Kingston, R.I.

36. Chubb, C. and Ewing, I.I. (1979) Am. J. Physiol. 237 E231.

37. Zirken, B.K., Ewing, L.L., Kromann, N. and Cochran, R.C. (1980) Endocrinology 107, 1867.

38. Samborskaya, E.P. and Ferdman, T.D. (1962) Byulletin' Eksperimental 'noi Biologii i Meditsiny 54, 110.

39. Samborskaya, E.P. (1964) Byulletin' Eksperimental 'noi Biologii i Meditsiny 57, 105.

40. Samborskaya, E.P. and Ferdman, T.D. (1966). Byulletin' Eksperimental 'noi Biologii i Meditsiny $62,96$.

41. Metzler, D.E. Biochemistry (1977) New York: Academic Press, p. 408 .

42. Sulimovici, S. and Boyd, G.S. (1968) Eur. J. Biochem. 3. 332 .

43. Sulimuvici, S. and Boyd, G.S. (1968) Steroids $12,127$.

44. Shimuzu, K. (1970) Biochim. Biophys. Acta $210,333$.

45. Lipscomb, H.S. and Nelson, D.H. (1960) Endocrinology 66, 144 .

46. Bacchus, H. (1957) Am. J. Physiol. 188, 303.

47. Gruber, K.A., Obrien, L.V. and Gerstner, R. (1976) Science 191, 472 .

48. Biswas, N.M. (1969) Endocrinology 85, 981.

49. Pintauro, S.J. Masters Thesis (1978) University of Rhode Island, Kingston.

50. Jenkins, P. (1967) Endocrinology 70, 267.

51. Pankov, Y.A. (1966) Fed. Proc. 25, T268.

52. Kitabchi, A.E. (1967) steroids $10,567$.

53. Cooper, D.Y. and Rosenthal, O. (1962) Arch. Biochem. Biophys. $96,331$.

54. Koritz, S.B. (1963) Arch. Biochem. Biophys. 100, 349. 
55. Staudinger, H.K., Krisch, K. and Leonhauser, A. Ann. N.Y. Acad. Sci. 92, 295.

56. Bielski, B.H.J. and Richter, H. (1975) Ann. N.Y. Acad. Sci. 258, 231 .

57. Michaelis, I. (1932) J. Biol. Chem. 96, 703.

58. Heath, H. and Fiddick, R. (1965) Biochem. J. 94, 114.

59. Devine, M.M. and Rivers, J.M. (1968) J. Nutr. 97, 295.

60. Degkwitz, E., Walsh, S., Dubberstein, M. and Winter, J. (1975) Ann. N.Y. Acad. Sci. 258, 201.

61. Degkwitz, E., and Staudinger, H.J. In Vitamin C Recent Aspects of Its Physiological and Technical Importance (1974). New York, John Wiley, p. 161-177.

62. Kirk, S.E. (1962) Vitamins and Hormones 20, 83.

63. Oesterling, M.J. and Long, L.N.H. (1951) Science 113, 241 .

64. Gombe, S., Odvor-Okelo, D., Bharaj, B. and Verjee, Z.H. (1977) Int. J. Vit. Nutr. Res. 47, 75.

65. Hornig. D. (1975) Ann. N.Y. Acad. Sci. 258, 103.

66. Kocen, B.D. and Cavazos, L.F. (1958) Proc. Soc. Expt. Biol. Med. 98, 485.

67. Jones, R.S., Peric-Golea, I. and Eik-Nes, K. (1958) Endocrinology 63,659 . 
APPENDIX 
Figure 1. Linearity of $3 B H S O R$ activity with varying protein concentrations in guinea pig testis microsomes. Incubations were run in the presence of $500 \mu \mathrm{M} \mathrm{NAD}, 5 \mathrm{mM} \mathrm{MgCl} 2,1 \%$ propylene glycol in . IM Tris, $\mathrm{pH} 7.4$ at $37^{\circ} \mathrm{C}$ for 5 minutes. Substrate was $10 \mu \mathrm{M}$ PREG and protein concentration was varied from 16 to $200 \mu \mathrm{g} / .1$ ml final volume. 


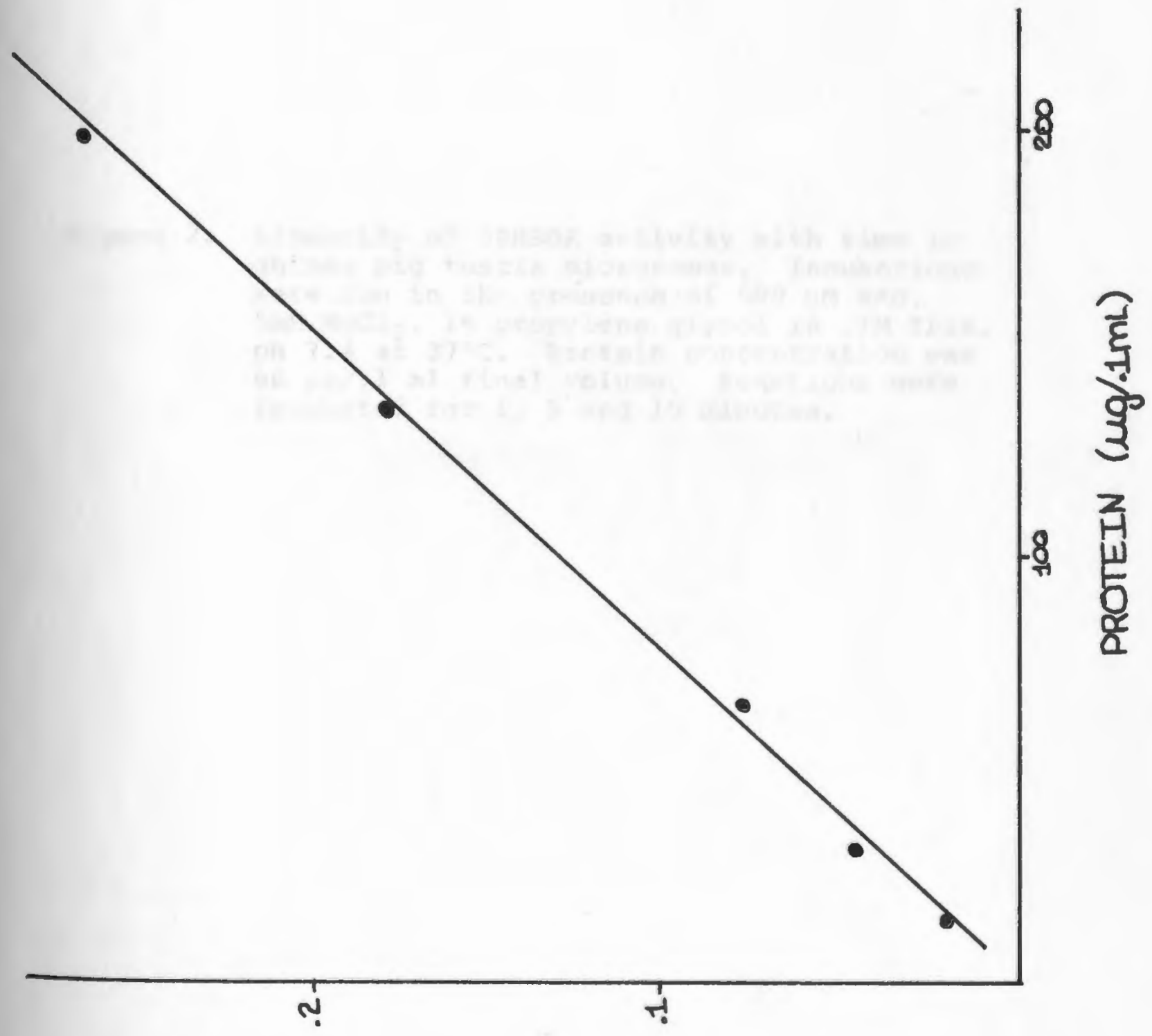

(ung/mu) boyd 
Figure 2. Linearity of 3BHSOR activity with time in guinea pig testis microsomes. Incubations were run in the presence of $500 \mu \mathrm{M} \mathrm{NAD,}$ $5 \mathrm{mM} \mathrm{MgCl}_{2}, 1 \%$ propylene glycol in . IM Tris, ph 7.4 at $37^{\circ} \mathrm{C}$. Protein concentration was $66 \mu \mathrm{g} / .1 \mathrm{ml}$ final volume. Reactions were incubated for 1,5 and 10 minutes. 



(buy/un) Dodd 
Arine, E. and Philpot,-R. M. (1976) J. Biol. Chem. 251, 3213. Association Official Analytical Chemists, Official Methods of Analysis (1980), 13th ed. Washington, D.C., p. 746.

Bacchus, H. (1957) Am. J. Physiol. 188, 303.

Basch, R.S. and Finegold, M.J. (1971) Bioche,. J. 125, 983.

Becker, S., Chubb, C. and Ewing, L. (1980) Am. J. Physiol. 239, RI84.

Betz, G., Tsai, D. and Hales, D. (1980) Endocrinology 107, 1055.

Betz, G., Tsai, D. and Weakley, P. (1976) J. Biol. Chem. 251, 2839.

Bielski, B.H.J. and Richter, H. (1975) Ann. N.Y. Acad. Sci. 258, 231.

Biswas, N.M. (1969) Endocrinology 85, 981.

Bogovich, K. and Payne, A.H. (1978) Fed. Proc. 37, 1579.

Chubb, C. and Ewing, L.L. (1979) Am. J. Physiol. 237, E231.

Chubb, C. and Ewing L.L. (1979) Am. J. Physiol. 237, E239.

Chubb, C. and Ewing L.L. (1979) Am. J. Physiol. 237, E247:

Cooper, D.Y. and Rosenthal, O. (1962) Arch. Biochem. Biophys. 96, 331 .

Degwitz, Z., Walsh, E., Dubberstein, M. and Winter, J. (1975) Ann. N.Y. Acad. Sci. 258, 201.

Devine, M.M. and Rivers, J.M. (1968) J. Nutr. 97, 295.

Dorfman, R.I., Forchielli, E. and Gut, M. (1963) Recent Progr. Hormone Res. 19, 258.

Eik-Nes, K.B. (1970) In: The Androgens of the Testis, edited by K.B. Eik-Nes, New York, Dekker, P. 10.

Eik-Nes, K.B. and Kekre, M. (1963) Biochim. Biophys. Acta 78, 449.

Ewing, L.L., Cochran, R.C., Zirkin, R. and Chubb, C.E. (1980) In: Testicular Development Structure and Function, edited by A. Steinberger and E. Steinberger, Raven Press, New York, p. 117-176. 
Fan, D. and Troen, P. (1975) J. Clin. Endocrinol. 4l, 563. Ford, H.C. and Engel, L.L. (1974) J. Biol. Chem. 294, 1363. Gombe, S., Odvor-Okelo, D., Bharaj, B. and Verjee, Z.H. (1977) In. J. Vit. Nutr. Res. 47, 75.

Gornall, A.G., Bardavill, C.J., David, M.M. (1949) J. Biol. Chem. 177, 757.

Gower, D.B. and Hazelwood, G.D.A. (1961) J. Endocrinol. 23, 253.

Gruber, K.A., Obrien, L.V. and Gerstner, R. (1976) Science $191,472$.

Hagen, A.A. and Eik-Nes, K.B. (1964) Biochim. Biophys. Acta 86,372 .

Halkerson, I.D.E., Eichors, J., Heckter, O. (1971) J. Biol. Chem. $\underline{263}, 374$.

Hall, P.F. In: The Testis, edited by A.D. Johnson and W.R. Gomes, Academic Press, New York, (1971) Vol. 1, p. 1-71.

Hall, P.F. and Koritz, S.B. (1964) Biochem. 3, 129.

Hall, P.F., Nishizowa, Z.Z. and Eik-Nes, K.B. (1963) Proc. Soc. Exptl. Biol. Med. 114, 791.

Heath, H. and Fiddick, R. (1965) Biochem. J. 94, 114.

Hochberg, R., Landany, S., Lieberman, E.S. (1976) J. Biol. Chem. 251,3320 .

Hologgitas, J.V. (1981) Ph.D. Dissertation, University of Rhode Island, Kingston.

Hosaka, M., Oshima, H. and Troen, P. (1980) Acta. Endocrinol. 94, 389 .

Hornig, D. (1975) Amn. N.Y. Acad. Sci. 258, 103.

Inano, H. and Tamaoki, B. (1974) Eur. J. Biochem. 44, 13.

Imai, H and Tamaoki, B. (1974) Biochem. Biophys. Res. Comm. $60,8$.

Jenkins, P. (1967) Endocrinology 70, 267. 
Jiminez, U. (1975) Ph.D. Dissertation, University of Rhode Island, Kingston.

Jones, R.S., Peric-Golea, L. and Eik-Nes, K. (1958)

Endocrinology 63, 659.

Kirk, S.E. (1962) Vitamins and Hormones 20, 83.

Kitabchi, A.E. (1967) Steroids 10, 567.

Knapstein, P., Wendleberger, F., Menzel, P., Dertel, G. and Touchstone, J.C. (1968) Steroids 12, 191.

Kocen, B.D. and Cavazos, L.F. (1958) Proc. Soc. Expt. Biol. Med. 98, 485.

Koritz, S.B. (1963) Arch. Biochem. Biophys. 100, 349.

Iineweaver, H. and Burk, D. (1934) J. Am. Chem. Soc. 56, 658.

Lipscomb, H.S. and Nelson, D.H. (1960) Endocrinology 66,

144.

May, J.V. (1978) Ph.D. Dissertation, University of Rhode Island, Kingston.

May, J.V., Hologgitas, J. and Purvis, J.L. (1978) Fed. Proc. 37, 1474 .

Menard, R.H. and Purvis, J.L. (1973) Arch. Biochem. Biophys. 154,8 .

Menard, R.H., Stripp, B. and Gillette, S.R. (1974)

Endocrinology 94, 1628.

Metzler, D.E. (1977) Biochemistry, New York, Academic Press p. 408 .

Michaelis, L. (1932) J. Biol. Chem. 96, 703.

Nakajin, S. and Hall, P.F. (1981) J. Biol. Chem. 256, 3871.

Nakajiin, S., Shively, J.E., Yuan, P. and Hall, P.F. (1981) Biochem. 20, 4037.

Neher, R. and Wettstein, A (1961) Acta Endocrinol. 35, 1.

Oshima, H., Fan, D. and Troen, P. (1975) J. Clin. Endocrinol. Metab. 40, 573. 
Osterling, M.J. and Long, C.N.H. (1951) Science 113, 241. Pankov, Y.A. (1966) Fed. Proc. 25, T268.

Pintauro, S.J. (1978) Masters Thesis, University of Rhode Island, Kingston.

Purvis, J.L., Canick, J.A., Latif, S.A., Rosenbaum, J.H., Hologgitas, J. and Menard, R.H. (1973) Arch. Biochem. Biophys. $159,39$.

Rosner, M., Hall, P.F. and Eik-Nes, K.B. (1965) Steroids 5, 199.

Rosner, S.M., Horitz, S. and Forsham, P.H. (1964) Endocrinology 75, 229.

Samborskaya, E.P. (1964) Byulletin' Eksperimental 'noi Biologii i Meditsiny 57, 105.

Samborskaya, E.P. and Ferdman, T.D. (1962) Byulletin' Eksperimental 'noi Biologii i Meditsiny'54, 110.

Samborskaya, E.P. and Ferdman, T.D. (1966) Byulletin' Eksperimental 'noi'Biologii i Meditsiny 62, 96.

Samuels, L.T. and Matsumoto, K. (1974) Endocrinology 94, 55 .

Schultz, R.M., Graman, E.V. and Engel, LL. (1977)

J. Biol. Chem. 252, 3775.

Shikita, M., Kakizaki, H. and Tamaoki, B. (1964)

Steroids 4 , 521 .

Shikita, M. and Talalay, P. (1979) Anal. Biochem. 95, 286.

Shimuzu, K. (1970) Biochim. Biophys. Acta 210, 333.

Slaunwhite, W.R. and Burgett, M.J. (1965) Steroids $\underline{6}$. 721.

Slaunwhite, W.R. and Samuels, L.T. (1956) J. Biol. Chem. 220,341 .

Staudinger, H.K., Kirsh, K. and Leonhauser, A. (1961) Ann. N.Y. Acad. Sci. 22, 295. 
Sulimovici, S. and Boyd, G.S. (1968) Steroids 12, 127.

Sulimovici, S. and Boyd, G.S. (1968) Eur. J. Biochem. 3, 332.

Sulimovici, S., Bartoov, B. and Lumenfeld, B. (1973)

Biochim. Biophys. Acta 321, 27.

Takumi, Y and Troen, P. (1972) J. Clin. Endocrinol. Metab. 34, 783.

Tamaoki, B. and Pincus, G. (1961) Endocrinology 64, 527.

Trappe, W. (1980) Biochem. Z. 305, 150.

Van Der Molen, H.J. and Eik-Nes, K. (1971) Biochim. Biophys. Acta 248, 343.

Van Der Molen, H.J., De Bruijin, H.W.A., Cooke, B.A., De Jong, F.H. and Rarmerts, F.F. (1973) In: The Endocrine Function of the Human Testis, edited by V.H.T. James, M. Serio and L. Martini New York, Academic Press, Vol. 1

Ward, M.G. and Engel, L.L. (1966) J. Biol. Chem. 241, 3147.

Yahaihara, T. and Troen, P. (1972) J. Clin. Endocrinol. Metab. 34, 783.

Yates, J. and Deshpande, N. (1975) J. Endocrinol. 64, 195.

Zannoni, V.G., Lynch, M., Goldstein, S. and Sato, P. (1974)

Biochem. Med. 11, 41 .

Zirkin, B.K., Ewing, L.L., Kromann, N. and Cochran, R.C. (1980) Endocrinology 107, 1867. 